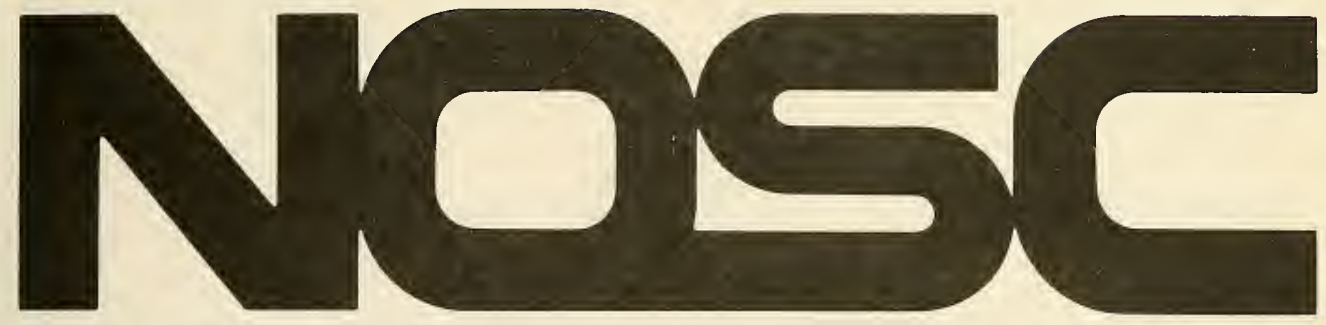

Technical Report 359

\title{
PERFORMANCE OF PHOTOVOLTAIC CELLS IN AN UNDERSEA ENVIRONMENT
}

\author{
JD Stachiw
}

1 January 1979

Final Report: March - October 1978

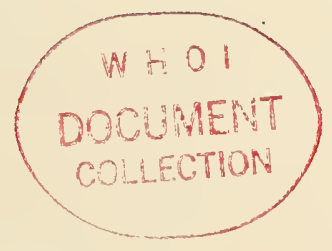




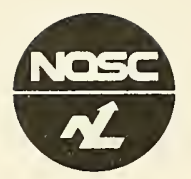

NAVAL OCEAN SYSTEMS CENTER, SAN DIEGO, CA 92152

AN ACTIVITY OF THE NAVAL MATER IAL COMMAND
RR GAVAZZI, CAPT USN
Commander
HL BLOOD

ADMINISTRATIVE INFORMATION

The work reported herein was performed from March through October 1978 by the staff of the Ocean Technology Department. The work was sponsored by the Director of Naval Laboratories as part of the Independent Research and Independent Exploratory Development (IR/IED) Program, Task Area ZF61512001. The author expresses his appreciation for assistance in performance of the field tests to the National Park Service, Crater Lake National Park, Oregon.

Released by

HR Talkington, Head

Ocean Technology Department 


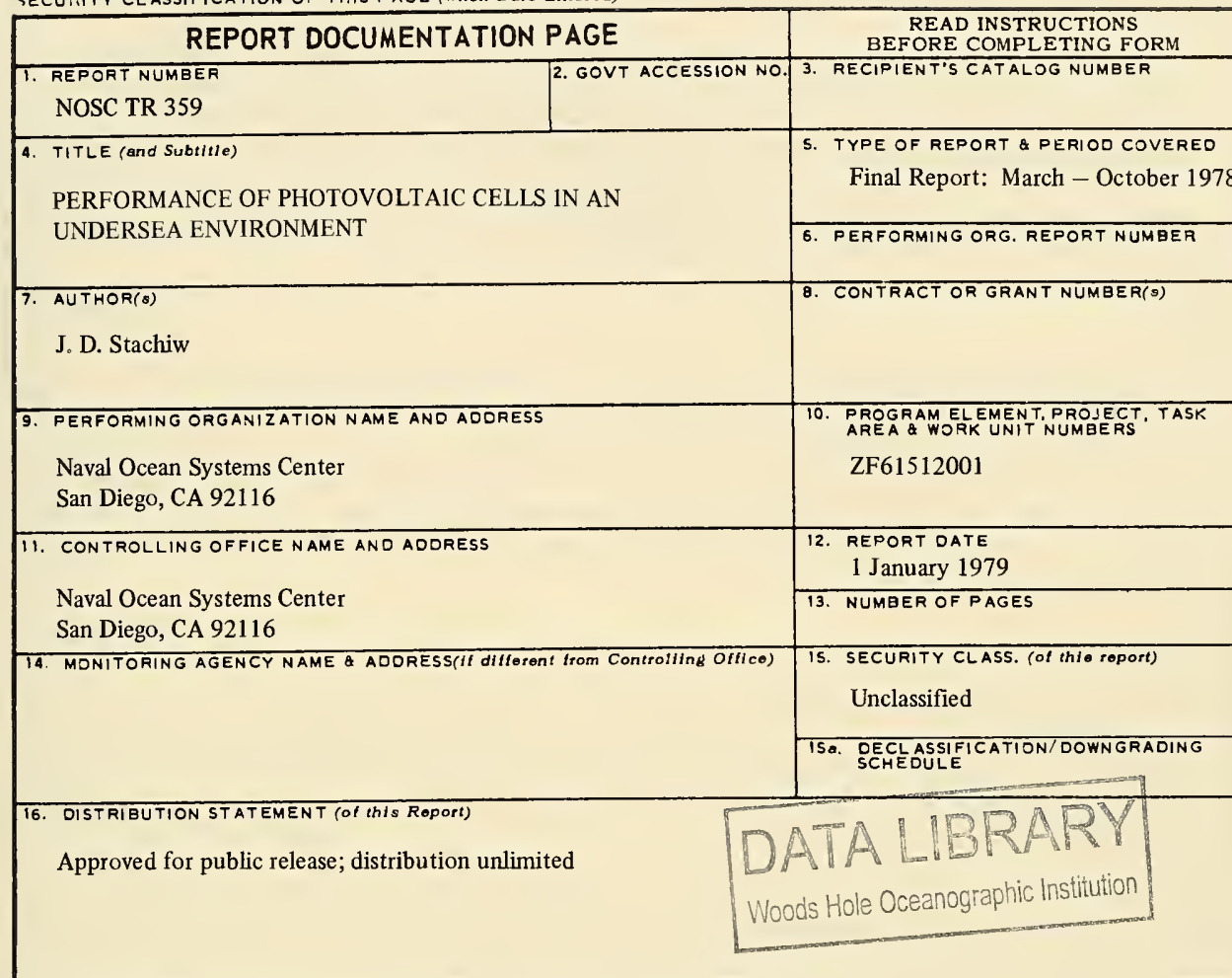

17. DISTRIBUTION STATEMENT (of the abstrect ontered in Block 20, if different from Report)

18. SUPPLEMENTARY NOTES

19. KEY WOROS (Continue on reverse alde if neces sery and identify by block number)

20. AESTRACT (Continue on reverse olde 11 noceseary and identity by block number)

Photovoltaic solar cells can serve as a reliable source of electric power for electronic instrumentation in temporarily or permanently submerged marine systems in the form of bottom installations, buoys, or remotely controlled unmanned vehicles. The power output of submerged solar cells is a function of solar insolation intensity on the water surface, depth of submersion, optical properties of water, temperature, and the orientation of the cell surface with respect to the sun. Experimental data were generated by submerging solar cell panels in different bodies of water with a 2.5 - to 95 -ft visual contrast limit, as defined by the observation of a submerged, 
standard, 12-in Secchi disc, and measuring their performance under load. The power output of horizontally oriented, upward-facing, photovoltaic cells submerged to the visual contrast limit depth was found to be a constant, equal to approximately 5 to 10 percent of the power generated by upward-facing, horizontally oriented cells in an atmospheric environment. The power output of the cells increased at lesser depths, until in the splash zone the output was essentially the same or higher than in the atmospheric environment. Based on these findings it can be concluded that high-efficiency silicon solar cells can serve as a practical electrical power supply in electronic devices for marine applications, if their depth of submersion is less than the visual contrast limit at the dive location. 


\section{SUMMARY}

\section{PROBLEM}

The U. S. Navy utilizes bottom-mounted, tethered, and floating self-contained electronic devices for detection, measurement, and recording of oceanographic, ocean surveillance, and antisubmarine warfare data. The operational life of these devices is in most cases limited by the storage capacity of electrochemical batteries which supply power for operation of electronic components. Any economical means to extend the operational life of these devices would make their operation significantly more cost effective.

\section{APPROACH}

Photovoltaic cells were selected as a possible source of power for trickle charging of batteries aboard submerged devices containing electronic instruments. Although it is known that sunlight intensity rapidly decreases with depth, it was hoped that there would be adequate illumination on photovoltaic cells below the water surface to generate sufficient power for trickle charging of batteries.

The evaluation of solar (photovoltaic power) cells for undersea power applications was conducted by submerging two solar cell panels to different depths and measuring the power output caused by downwelling and upwelling solar irradiance. To establish the lower and upper limits of solar cell performance, tests were conducted in waters whose visibility varied from excellent to poor.

\section{RESULTS}

The power output of solar cells decreased rapidly with depth and water transparency. Experimental data indicate, however, that sufficient power density is generated by solar cells from the air-sea interface to the visual contrast limit depth (Secchi depth) to be of practical value to the designer of power supplies for submerged electronic devices. The power density of silicon solar cell panels was found to vary in this depth range from $12 \mathrm{~W} / \mathrm{ft}^{2}$ at the surface to $1 \mathrm{~W} / \mathrm{ft}^{2}$ at the visual contrast limit depth under standard $100-\mathrm{mW} / \mathrm{cm}^{2}$ sun insolation intensity.

\section{RECOMMENDATION}

Solar cells should be seriously considered as power supplies for electronic devices operating in the ocean between the air-sea interface and the visual contrast limit depth. In the open ocean, the lower limit of this depth range varies from 20 to $100 \mathrm{ft}$, depending on location and time of the year. 


\section{TABLE OF CONTENTS}

INTRODUCTION . . . page 3

BACKGROUND . . . 3

Solar Cell Construction . . . 3

Solar Cell Performance. . . 6

Solar Cell Arrays... 7

SOLAR CELLS IN MARINE SERVICE . . 8

Above-Water Applications . . . 8

Submerged Applications ...9 9

Overview of Problem Areas... 9

Underwater Insolation ...99

Power Output of Submerged Solar Cells . . . 11

UTILIZATION OF SUBMERGED SOLAR CELLS . . . 34

Power Output . . 34

Protection Against Marine Environment . . 36

DESIGN CONCEPTS . . . 37

Markers for Underwater Hazards to Navigation . . . 38

Underwater Sentinels . . 38

Roving Patrol . . . 38

CONCLUSION . . 39

REFERENCES . . . 40 


\section{INTRODUCTION}

Photovoltaic cells, commonly called solar cells, have for many years served as a reliable source of electric power for satellites. ${ }^{1}$ The power output of solar cells at that location is maximized due to absence of the earth's atmosphere, which would otherwise absorb some of the sun's radiation. As a result of solar cell technology developed for outer space applications, the cost of high-efficiency silicon solar cells has decreased progressively from approximately $\$ 100 / \mathrm{W}$ to less than $\$ 25 / \mathrm{W}$. At this price, solar cells are rapidly becoming an at tractive source of electrical power for many terrestrial applications that require a steady supply of direct current for charging storage batteries. The absence of moving parts and associated maintenance, as well as total independence of fuel supplies, makes solar cells very cost effective for supplying electric power to electronic instrumentation at remote locations.

Solar cells have not yet been utilized as sources of electric power for electronic instrumentation mounted in submerged marine electronic devices. The reasons for this are many: the high cost of the cells, the lack of data on the effect of submergence on power output, and the detrimental effect of biofouling. This state of affairs will change in the near future as (1) improved fabrication technology lowers the cost of solar cells, (2) performance data for submerged cells become available and (3) effective approaches are developed to control biofouling on solar cell surfaces submerged for long periods of time. This report summarizes an exploratory study conducted in this technological area by the Naval Ocean Systems Center, San Diego, California.

\section{BACKGROUND}

\section{SOLAR CELL CONSTRUCTION}

Solar cells represent semiconductor devices capable of converting light directly into electricity. The most efficient one developed to date for practical applications is a silicon solar cell; its power output is in the 12- to 15-percent range of incident normal solar insolation. Because pure silicon is a poor conductor of electricity, it is doped with other elements to make it more conductive. The addition of phosphorus during the growth of the silicon crystal develops a negative charge carrier; such silicon is designated n-type. The addition of boron creates positive charge carriers; such silicon is designated p-type.

The typical silicon solar cell consists of a thin slice of boron-doped silicon, which has been diffused on one side under high temperature by phosphorus. The boundary between the p-type and n-type materials constitutes the p-n junction. When the photon from the sun strikes an electron near the p-n junction region, a negative-charge (electron) and a positivecharge (hole) pair is created. The negative charge will now travel toward the n-type silicon region, while the positive charge will move to the p-type silicon region.

1. Kelly, B. P., Eckert, J. A., and Berman, E., "Investigation of Photovoltaic Applications," presented at International Congress on The Sun in the Service of Mankind, July 1973, Paris, France. 
The electric charges accumulating on the n- and p-type surfaces of the solar cell are gathered and siphoned off by means of metallic collectors fused to both surfaces. The collector on the back side of the silicon wafer completely covers the entire area, while the one on the top covers the area only partially so that light can impinge upon the n-type silicon surface with only a minimum of obstruction from the metallic grid (figure 1). The configuration, composition, and method of applying the collectors to cell surfaces vary from one manufacturer to another. To increase the power output further, the lighted surface is covered with an antireflective coating. 

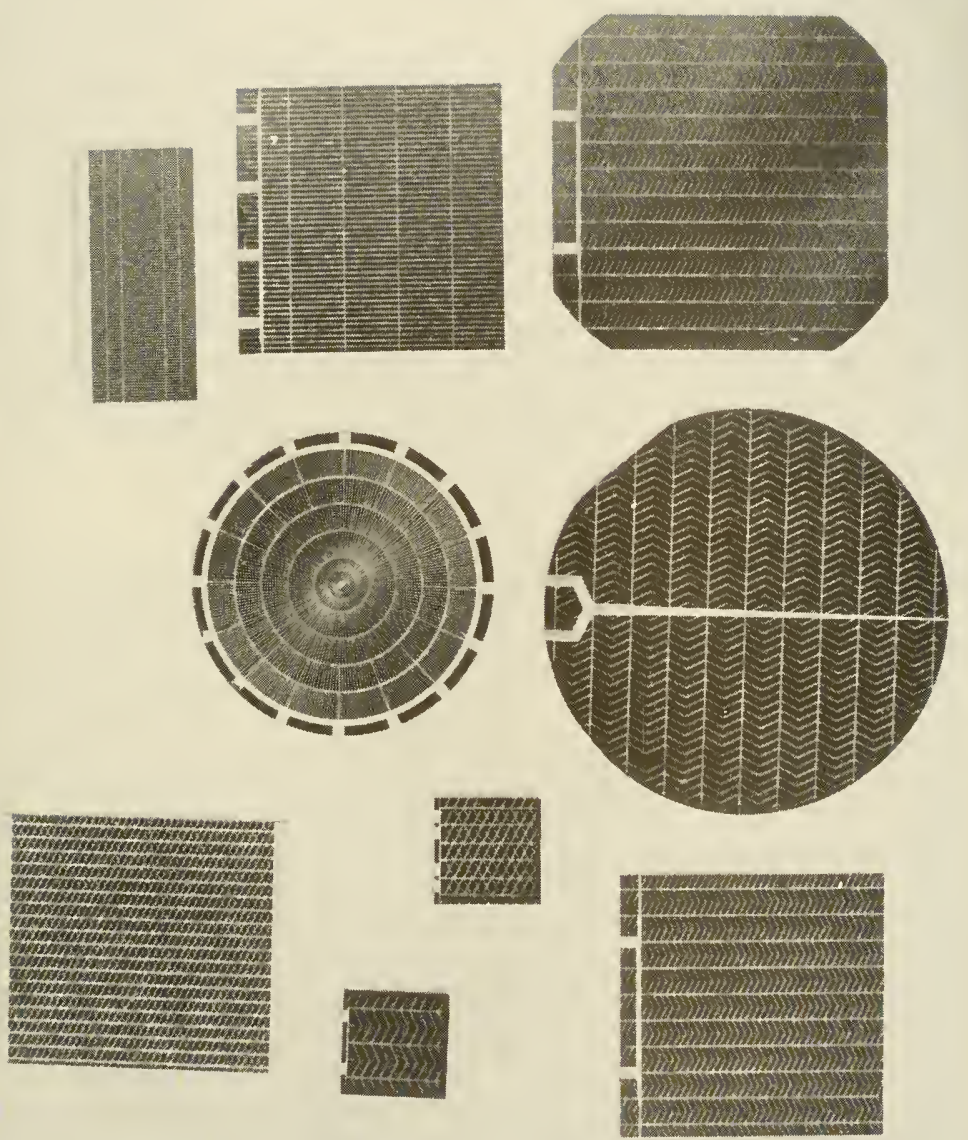

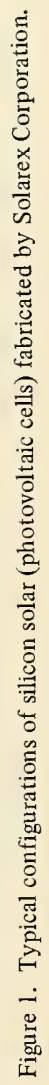




\section{SOLAR CELL PERFORMANCE}

The power output of silicon solar cells varies with their area and with the temperature, intensity, and spectral composition of the light impinging on the light-sensitive surface. The potential of a single cell is independent of its size and remains constant in the $0.45-$ to $0.5-\mathrm{V}$ range over a wide range of illumination intensities and ambient operating temperatures (figures 2 and 3 ). However, the amount of current generated by a single cell is directly proportional to the area of the cell and the solar light intensity. Changing the spectral composition of impinging light will also influence the current output as the quantum yield of solar cells varies with the wavelength of light (figure 4).

Since the power output (voltage $X$ current) of a single cell is primarily a function of light intensity, steps must be taken to maximize the intensity of light falling upon a solar cell. This is accomplished by minimizing obstructions to sunlight and maximizing its intensity. The first is done by keeping the thickness of the protective cover to a minimum (decreasing transmission losses) and eliminating the air space between the protective cover and the lightsensitive surface of the solar cell (decreasing reflection losses). The second is performed by aligning the light-sensitive surface of the cell at right angles to the rays of the sun and by concentrating sunlight upon the surface of the cell with mirrors or lenses. If sunlight is concentrated, steps must be taken to keep the solar cell cool to minimize power output loss caused by the increased ambient temperature of the cell.

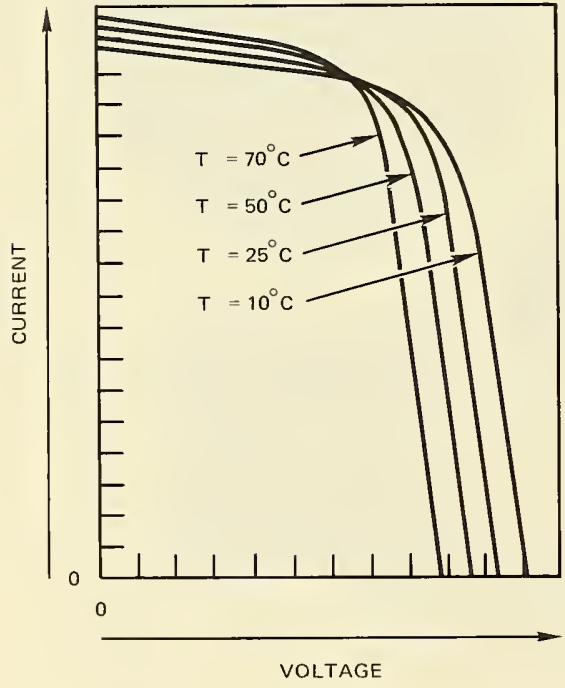

Figure 2. Effect of ambient cell temperature on the electrical performance of silicon solar cells.

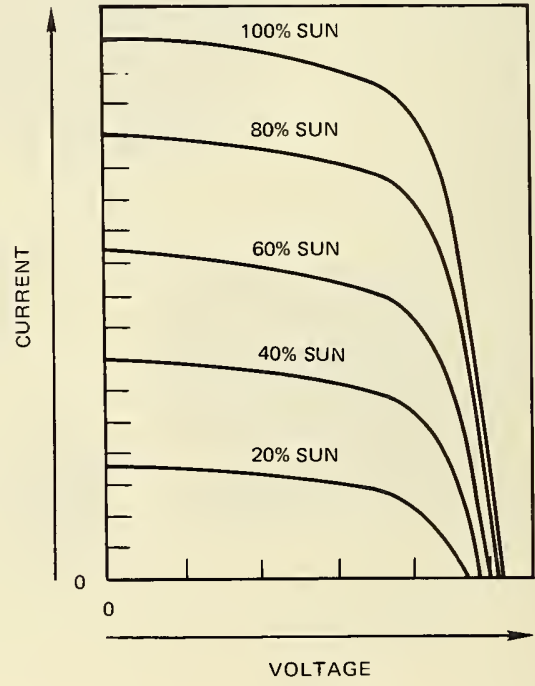

Figure 3. Effect of insolation intensity on the electrical performance of silicon solar cells. 


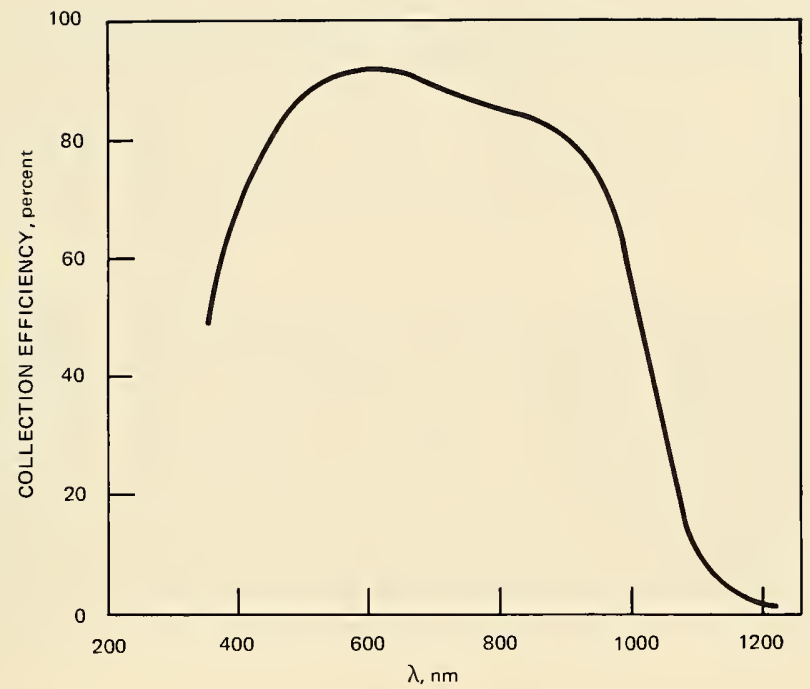

Figure 4. Typical spectral response of low-light-level, terrestrial, silicon solar cells fabricated by Solarex Corporation.

\section{SOLAR CELL ARRAYS}

Because the power output of a single solar cell is generally not adequate for its intended application, an array of cells must be employed. The leads from the cells may be connected in series or in parallel, depending on the total voltage required. The desired voltage may be also attained by incorporating one of the following: (1) an oscillator circuit for converting the low-voltage, direct-current (DC) output of the cells into a low-voltage, alternating current (AC), (2) a transformer which raises available $\mathrm{AC}$ voltage to any desired value, and (3) a rectifier which converts the AC output of the transformer into DC at the same voltage as the $\mathrm{AC}$ output of the transformer.

The major shortcoming of connecting cells in series is that for optimization of the power output all cells must have identical electrical performance characteristics and be illuminated with light of the same intensity. In outer space or in fixed terrestrial applications, this poses no problem as the sunlight illuminating an array at any given instant is generally the same intensity for all cells. However, this is not valid in nonfixed terrestrial applications, for example, cells mounted on the top and sides of a portable radio housing. Here the intensity of illumination may vary substantially from one cell to another, depending on its location and the orientation of the radio housing to the sun.

When the illumination of cells connected in series is nonuniform, the power output of the series-connected solar cell array decreases out of proportion to the loss of illumination 
experienced by a single, or several, cell(s). The reason is that cells with less illumination act like resistors through which the current generated by other solar cells in the circuit must pass. Thus, for example, in a typical array consisting of 15 cells connected in series, the total current output decreased by 66 percent from $450 \mathrm{~mA}$ when the insolation on a single cell was decreased from 80 to $15 \mathrm{~mW} / \mathrm{cm}^{2}$. In this case, an 81 -percent decrease in illumination intensity on a single cell resulted in a 66-percent decrease in the total power output of the solar array. If the same 15 solar cells in the array had been connected in parallel, the decrease would have been only 5.5 percent of the total power output from the array.

In most applications, solar cell arrays are used for charging batteries. As long as the potential of the array exceeds that of the battery, current will flow to the battery and charge it. If the light intensity decreases to such a degree that the array's voltage drops below that of the battery, the current will reverse and the battery will discharge through the array with all cells acting like resistors. To preclude discharge of batteries through the cells during periods of darkness and avoid possible damage because of overheating, a blocking diode acts like a one-way valve that allows the current to flow from the cells to the batteries with very little resistance while effectively blocking the flow of current from the battery to the cells. Blocking diodes are also employed to protect individual cells or groups of cells wired in parallel from acting like resistors when some of them become shaded while others are still exposed to bright sunlight.

\section{SOLAR CELLS IN MARINE SERVICE}

\section{ABOVE-WATER APPLICATIONS}

When solar cells are utilized to supply electric power to marine devices located above the ocean surface, few problems beyond those found in terrestrial applications are encountered. Problems not commonly found in terrestrial applications are continuous or intermittent water spray, defecation of birds, and dense fog.

Water spray does not pose a major problem, as embedding solar cells in clear silicon rubber, epoxy, polyester, or acrylic resins makes them waterproof without significantly decreasing their power output.

The defecation of birds is a more serious matter, as it can totally shade the surface of the cell in a short period of time and thus reduce its electric output to zero. Since it is virtually impossible to keep birds from alighting on any object protruding above the water surface, the only solution is to deny the birds a foothold on the surface of the array. This is easily accomplished by covering the individual solar cell panels with smooth acrylic or glass sheets and arranging them on top of the buoy in the shape of a truncated pyramid capped with a sharp plastic tip. As a result of this arrangement, there is at most a foothold for only one bird.

The performance of solar celis is also severely degraded by the presence of dense fog. Since fog is a common occurrence in coastal areas, it must be considered when the power output of a solar cell array is calculated. 
To date, solar cells have been successfully used in many navigational aids at remote coastal locations, where the periodic recharging or exchange of discharged batteries would present a severe problem in logistics.

\section{SUBMERGED APPLICATIONS}

\section{Overview of Problem Areas}

Submerged applications for solar cells pose a real technical challenge. Their power output is significantly less than in above-water applications, and the solar cells and associated electrical connectors mist remain dry, withstand hydrostatic pressure, and remain free of biofouling so that their marginal power output is not completely eliminated. Because of these problems, solar cells have not been utilized as power supplies for submerged navigational or oceanographic devices, although the above mentioned technical problems can be solved with existing technology. Because of its interest in ocean technology, NOSC sponsored an exploratory study into the area of submerged solar cells. These findings, summarized in this report, should help provide much of the technological basis and encouragement for design of submerged marine electronic devices powered by solar cells.

\section{Underwater Insolation}

Sunlight striking the water surface is either partially or totally reflected from the surface, depending on the angle that the rays make with a vertical to the water surface. At normal incidence ( 0 -deg angle with vertical) on a calm water surface the reflectance is only 2 percent, while at incidence angles in excess of $53 \mathrm{deg}$ (Brewster's angle for seawater) the reflectance rapidly increases until at $90 \mathrm{deg}$ all light is reflected and none transmitted into the water (figure 5). Based on these data, it can be deduced that in the early morning and late afternoon the oblique incidence angle of the sun's rays causes a significant portion of the sunlight to be reflected from a smooth water surface rather than transmitted. The presence of large waves, however, tends to negate this effect to some degree, as the slopes of waves facing the sun decrease the angle of incidence thus decreasing the percentage of light that would otherwise be reflected from a smooth water surface. The reflectance of the smooth water surface in the early morning and late evening hours is also somewhat decreased if the sky is completely overcast. This phenomenon can be explained by the fact that an overcast sky diffuses the light and thus all rays do not strike the surface at an oblique angle. The transmission of sunlight through a calm water surface under overcast skies or through rough water surface under clear skies is approximately 92 percent regardless of the sun's elevation. ${ }^{2}$

The rays of the sun which are not reflected by the water surface refract towards the vertical, since the seawater's index of refraction (1.34) is higher than that of air. The rays which enter the water encounter absorption and backscatter, which adversely affect propagation. Since water acts like a selective filter, the spectral composition of refracted sunlight will change with depth and quantity of dissolved organic matter in the water. Measurements

2. Schenck, H., Jr., and Kendall, H. W., "Underwater Photography," Cornell Maritime Press, Cambridge, MD 1957. 


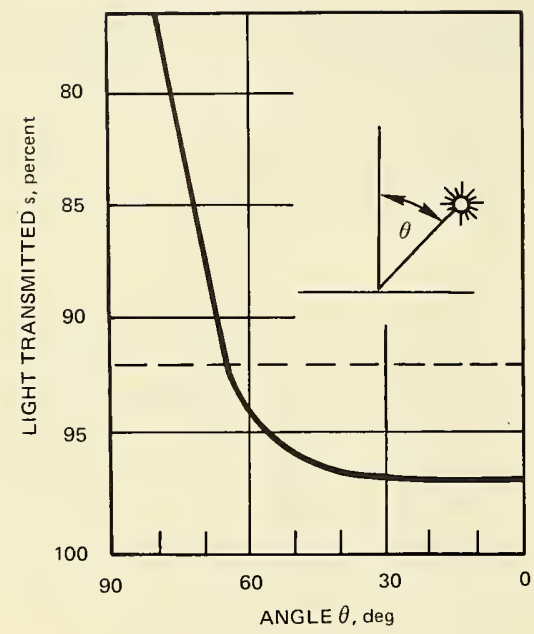

Figure 5. Transmission of light through air-water interface as a function of incidence angle; the dotted line indicates the transmission of light under heavy overcast which diffuses solar insolation.

performed by Taylor and $\mathrm{Smith}^{3}$ show that only wavelengths of light in the 480 -nm region are transmitted with little attenuation in clear water. Other wavelengths are rapidly filtered out. As a result of this selective filtering process, light with wavelengths outside the 450 - to $550-\mathrm{nm}$ range (blue-green) has been almost totally filtered out at a depth of $25 \mathrm{~m}$ (figure 6). Thus, the selective attenuation of the sunlight spectrum decreases not only the overall intensity of sunlight at a given depth, but also its spectral composition.

Because of the selective attenuation to which solar radiation is subjected in water, the output of the solar cells drops rapidly with depth. If the typical spectral response of a silicon solar cell (figure 4) is compared with the composition of spectral irradiance at depths in excess of $25 \mathrm{~m}$ (figure 6) it becomes obvious that only approximately 25 percent of the potential solar cell power is capable of responding to the available light intensity at that depth.

Diffused attenuation of sunlight is the major obstacle to light propagation only in waters with exceptional optical properties, i.e., the visual contrast limit depth is in excess of $25 \mathrm{~m}$. In seawater with typical optical properties, i.e., the visual contrast limit depth is about $5 \mathrm{~m}$, the decrease in underwater irradiance with depth is primarily caused by the suspended animate and inanimate water which either reflects and/or absorbs the downwelling irradiance. Estuaries of rivers, harbors, and bays are the primary locations of water with visibility less than $5 \mathrm{~m}$.

3. Tyler, J. E., and Smith, R. C., "Measurements of Spectral Irradiance Underwater," Gordon and Breach Science Publishers, New York, NY 1967. 


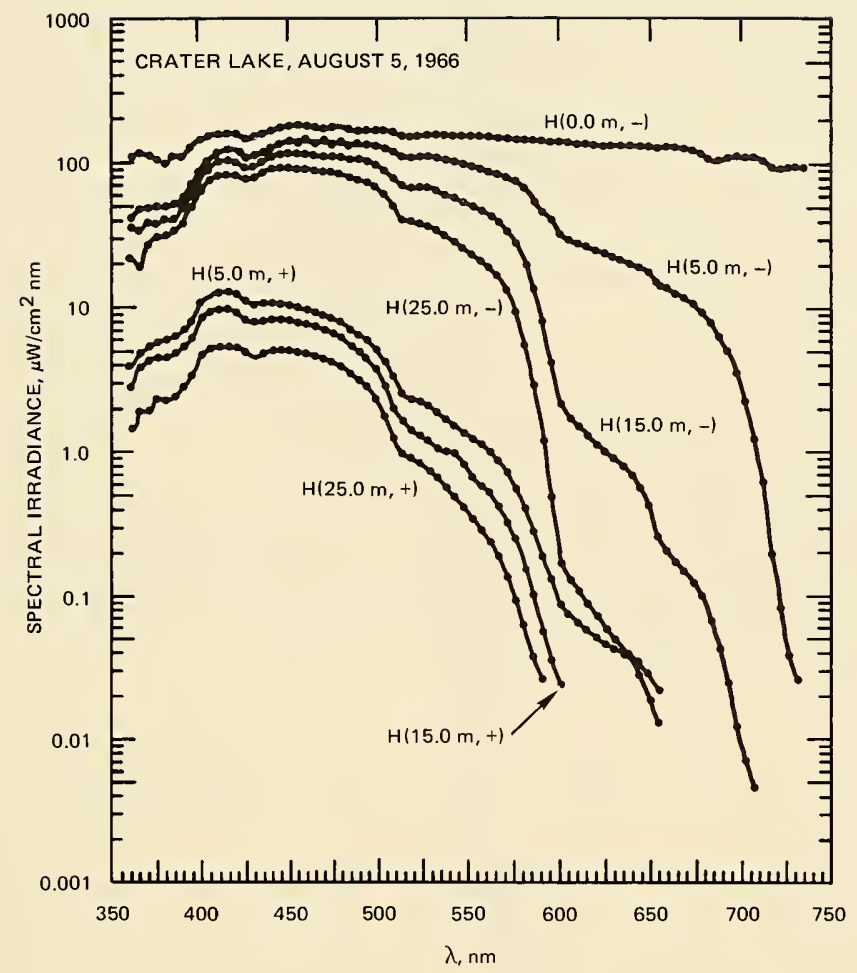

Figure 6. Spectral composition of downwelling and upwelling irradiance in lake water with 106-ft Secchi visibility (references 3 and 6).

The clarity of water in seas and oceans is not a constant, but varies with location, time of the year, and weather conditions. The designer of an underwater solar cell power supply must consider these factors or the solar cell array will be either too big or too small to supply the required electrical power for the electronics in a submerged marine device at a given location.

\section{Power Output of Submerged-Solar Cells}

Approach. To provide general values of power output expected from solar cells submerged to different depths in open sea, coastal, and lake waters, a set of solar cell panels was 
lowered to different depths at various locations and their power output was monitored by electronic instrumentation. The objective of this exploratory field study was to establish a first-order empirical relationship between solar cell performance and its operational depth. To make the exploratory study practical, the optical properties of water were measured with a simple Secchi disc, which defines underwater visibility in terms of contrast-limited range.

Measurement of the power output by the two solar cell arrays fabricated for this purpose was first performed under laboratory conditions in air at the test facilities of the fabricator, Solarex, Inc. To define the baseline performance of the two identical solar cell arrays, their potential and current outputs were measured under artificial sunlight whose intensity was varied from 1.0 to 0.01 standard suns at ambient temperatures from 2 to $71^{\circ} \mathrm{F}$ (figures 7, 8, and 9). These plots of potential as a function of current (VI plots) show that the current output of the solar array is directly proportional to the light intensity, if the spectral composition of the light remains approximately the same. The potential at which the maximum power output was observed remained essentially the same through the entire range of variations in sunlight intensity. As the ambient temperature decreased, the maximum current decreased, the maximum potential increased, and the maximum power (product of current and voltage) increased. Thus, it could be concluded that these solar cell arrays were well suited for undersea applications, as water cooling increased the maximum power output and the relationship between the maximum power output and the solar light intensity remained linear even at 1 percent of standard sun insolation. 


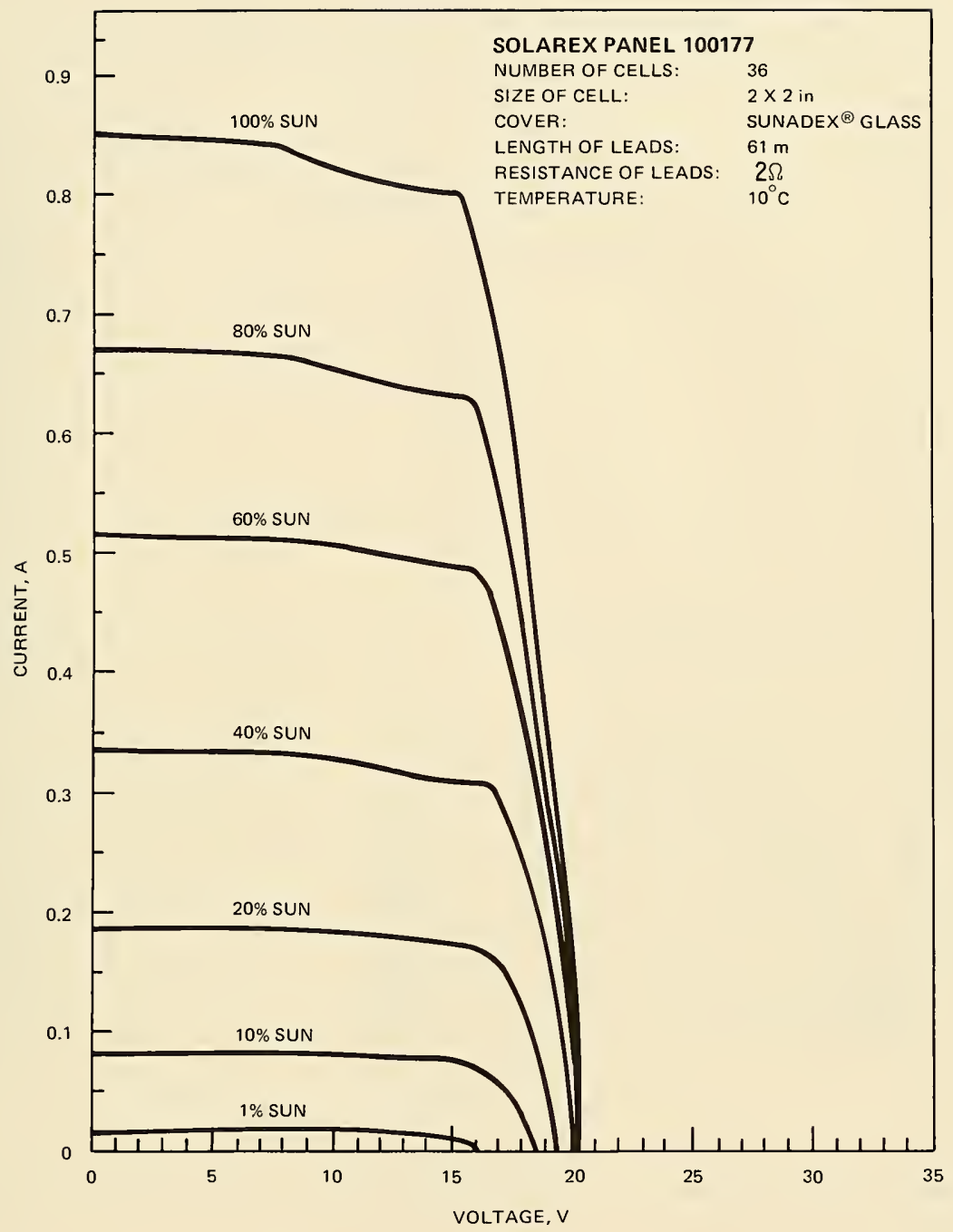

Figure 7. Electrical performance of Solarex solar cell panel 100177 under varying levels of insolation in controlled laboratory conditions. 


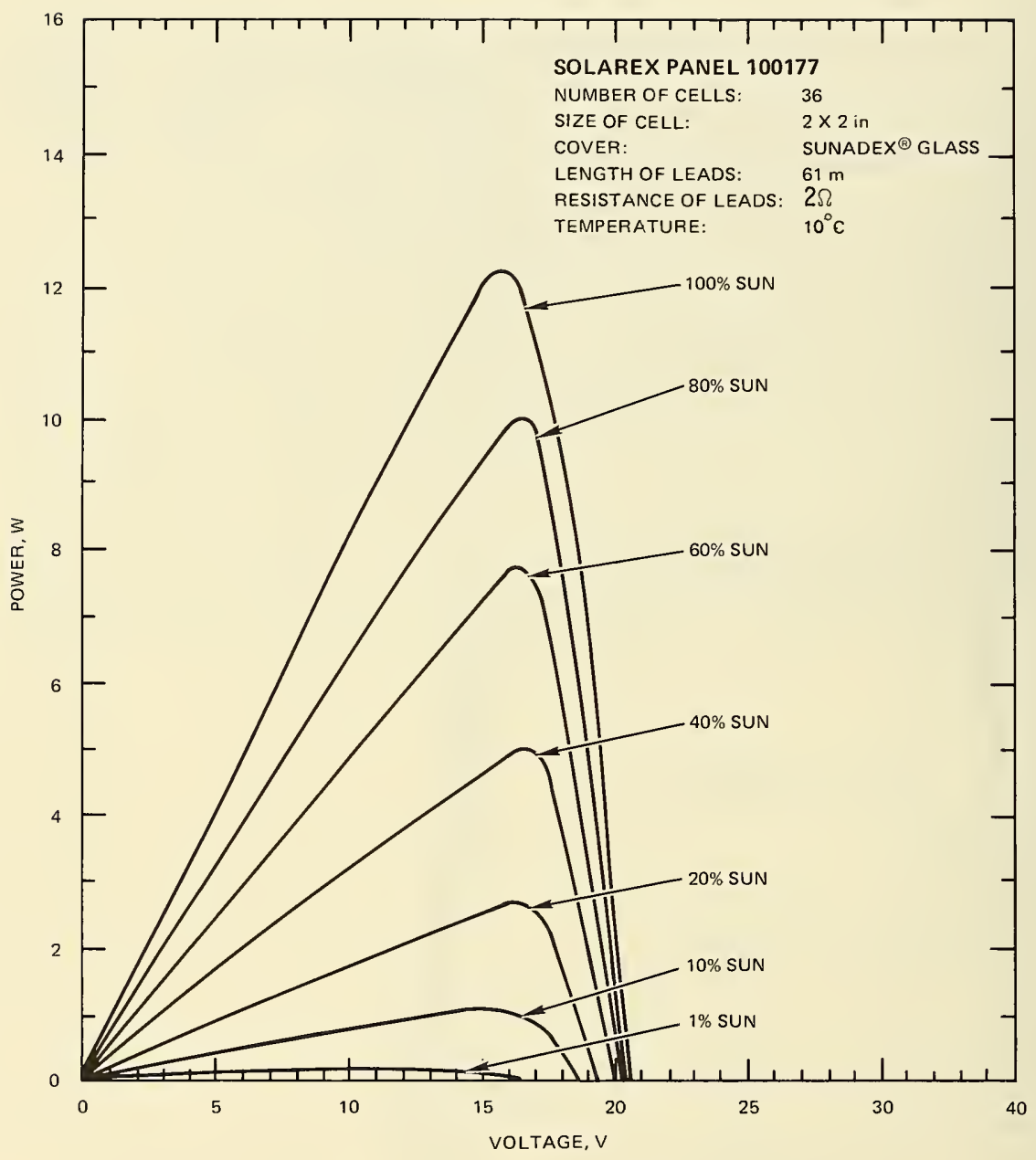

Figure 8. Power output of the solar cell panel whose electrical performance characteristics are shown in figure 7. 


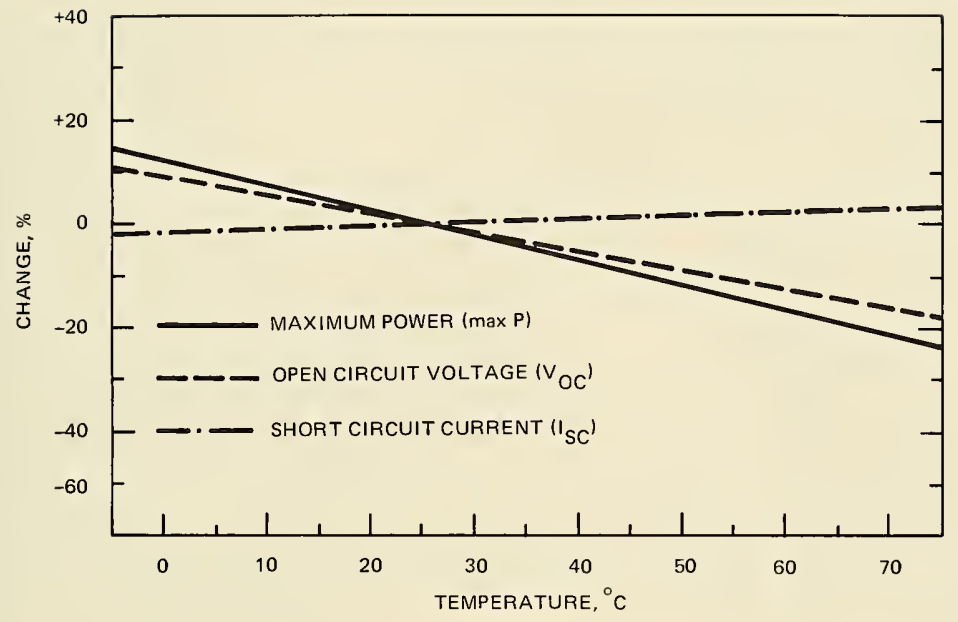

Figure 9. Effect of ambient temperature on the electrical performance of Solarex silicon solar cells in panel 100177.

Test Setup. Each solar array consisted of 36, high performance, 2- by 2 -in silicon cells connected in series and bonded to a tempered Sunadex ${ }^{\circledR}$ glass panel (figure 10). The backs of the cells, as well as the wiring between the individual cells, were protected against water by encapsulation in silicon rubber. Each array was provided with 200-ft-long, teflon-insulated pigtails for measurement of power output during submersion to a maximum depth of $200 \mathrm{ft}$ $(61 \mathrm{~m})$. To facilitate performance of the field tests, the two solar cell arrays were mounted back-to-back on a wooden frame, which was suspended horizontally by a nylon rope from a boat-mounted reel (figure 11). The upward-facing array responded to downwelling irradiance, while the downward-facing array responded only to upwelling irradiance at a given depth. 


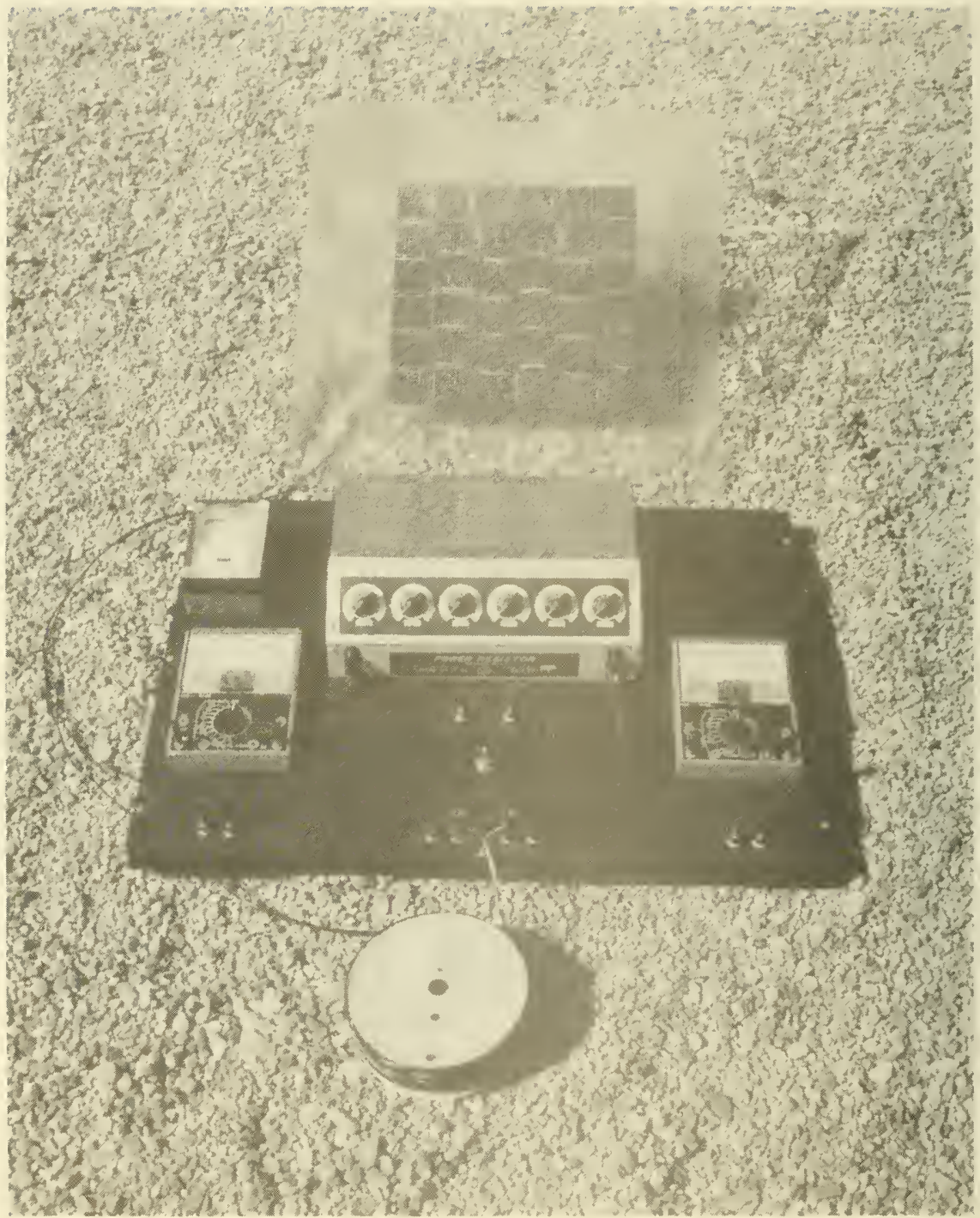

Figure 10. Equipment utilized for measurement of electrical power output by submerged solar cells. The variable resistance box allowed varying the magnitude of the electrical load across the leads from solar cells. 


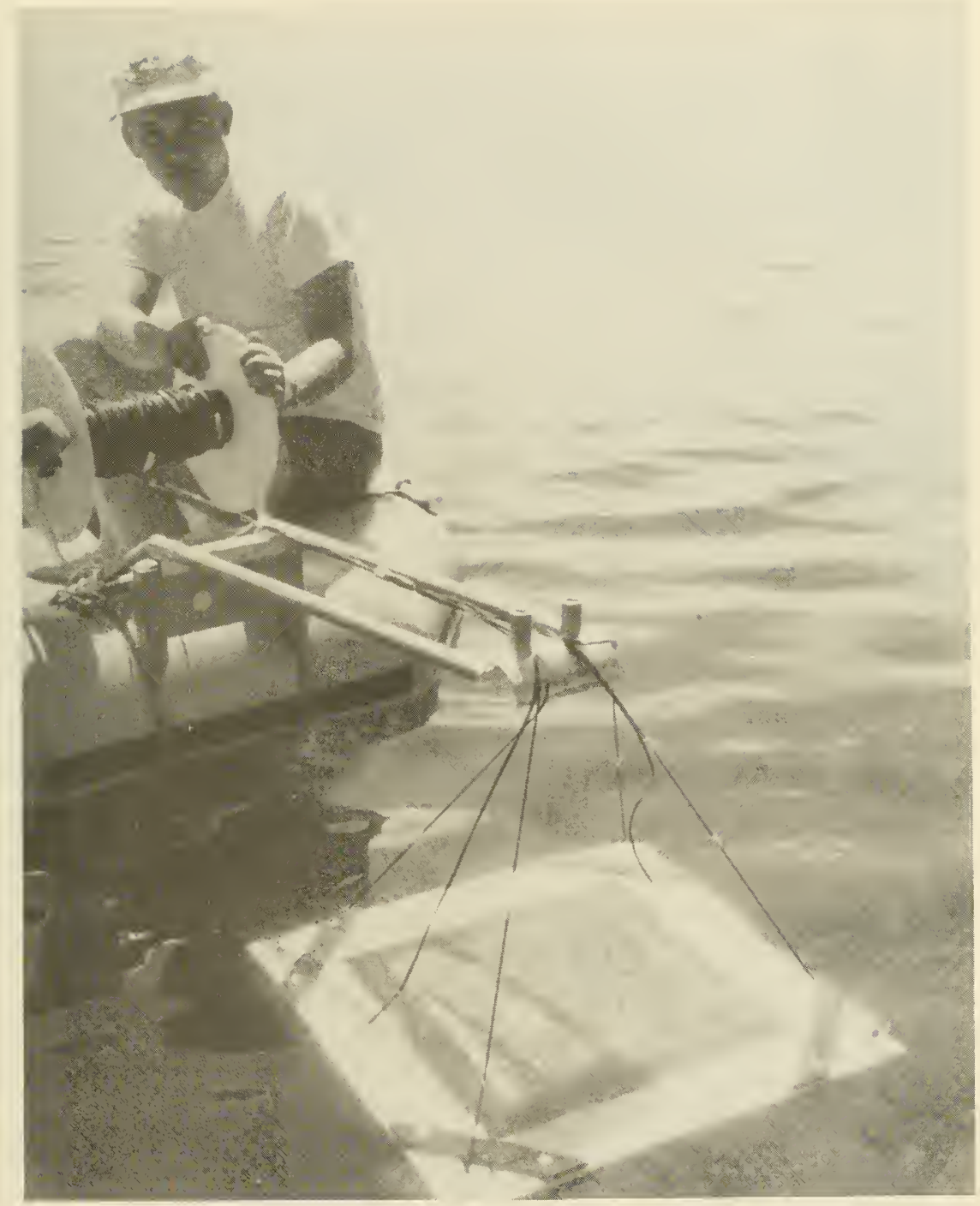

Figure 11. Deployment of solar cell panels from a surface raft by means of a hand-operated winch. Note that the two identical solar cell panels are mounted back-to-back in the wooden frame; the upward-facing panel measures downwelling irradiance, while the downward-facing panel measures the upwelling irradiance. 
Experimental Procedure. The typical field test consisted of measuring ( 1 ) the underwater visibility (visual contrast limit depth) with a 12-in-diameter Secchi disc (figures 12 and 13), (2) solar insolation on an imaginary horizontal plane just above the water surface with a portable insolation meter, and (3) current and voltage from the individual solar cell arrays. The voltage and current readings from the upward- and downward-facing solar arrays were recorded separately for each depth, as they represented the responses of the arrays to downwelling and upwelling irradiance. To obtain the complete VI plot for each depth, a resistor decade box was connected to the leads from the arrays and different resistors were switched into the circuit while the magnitudes of current and voltage were read by a voltmeter and an ammeter (figure 14). Typical values of resistors used for applying electrical loads to the solar cell circuit were $1,5,10,30,70,100,200,1000$, and 10,000 ohms.

Since the optical properties of water are not only a function of geographical location but also of time of year and weather conditions, it would have been presumptuous to take many field readings until the performance of submerged solar cells could be definitely established for all conceivable ambient water and weather conditions. Readings were instead taken only to establish typical power performance curves for solar cells at several depth levels in waters with widely ranging visibilities. This was accomplished by measuring the performance of solar cells submerged in waters with visibilities of $95,16.5,8$, and $2.5 \mathrm{ft}(29,5,2.4$ and $0.75 \mathrm{~m})$. The readings obtained in water with a $95-\mathrm{ft}$ visibility $(29 \mathrm{~m})$ serve as the upper limit of expected performance, while the readings taken in water with a 2.5 -ft visibility $(0.75$ $\mathrm{m})$ are the lower limit. The upper limit could logically represent visibility attained by water in tropical and polar regions, while the lower limit could represent visibility encountered in estuaries of rivers, shallow bays, and polluted harbors. The readings taken in water with 16.5$\mathrm{ft}$ visibility $(5 \mathrm{~m})$ are conservative values of solar cell performance in seawater near wavebattered shores. To maintain reasonable comparability between the readings taken at different locations, they were taken only at noon when the solar insolation measured at the horizontal water surface was in the $75-$ to $85-\mathrm{mW} / \mathrm{cm}^{2}$ range. 


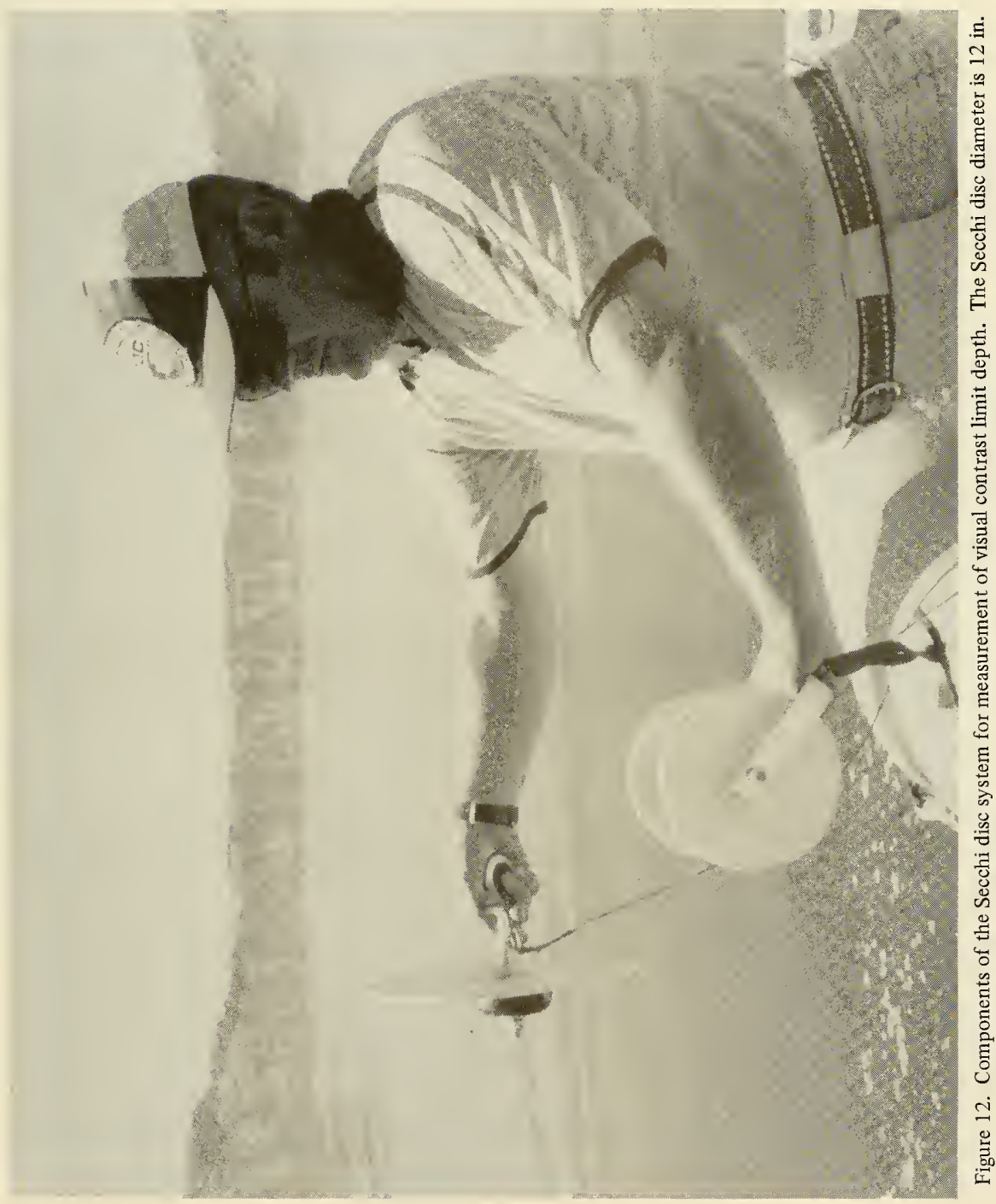




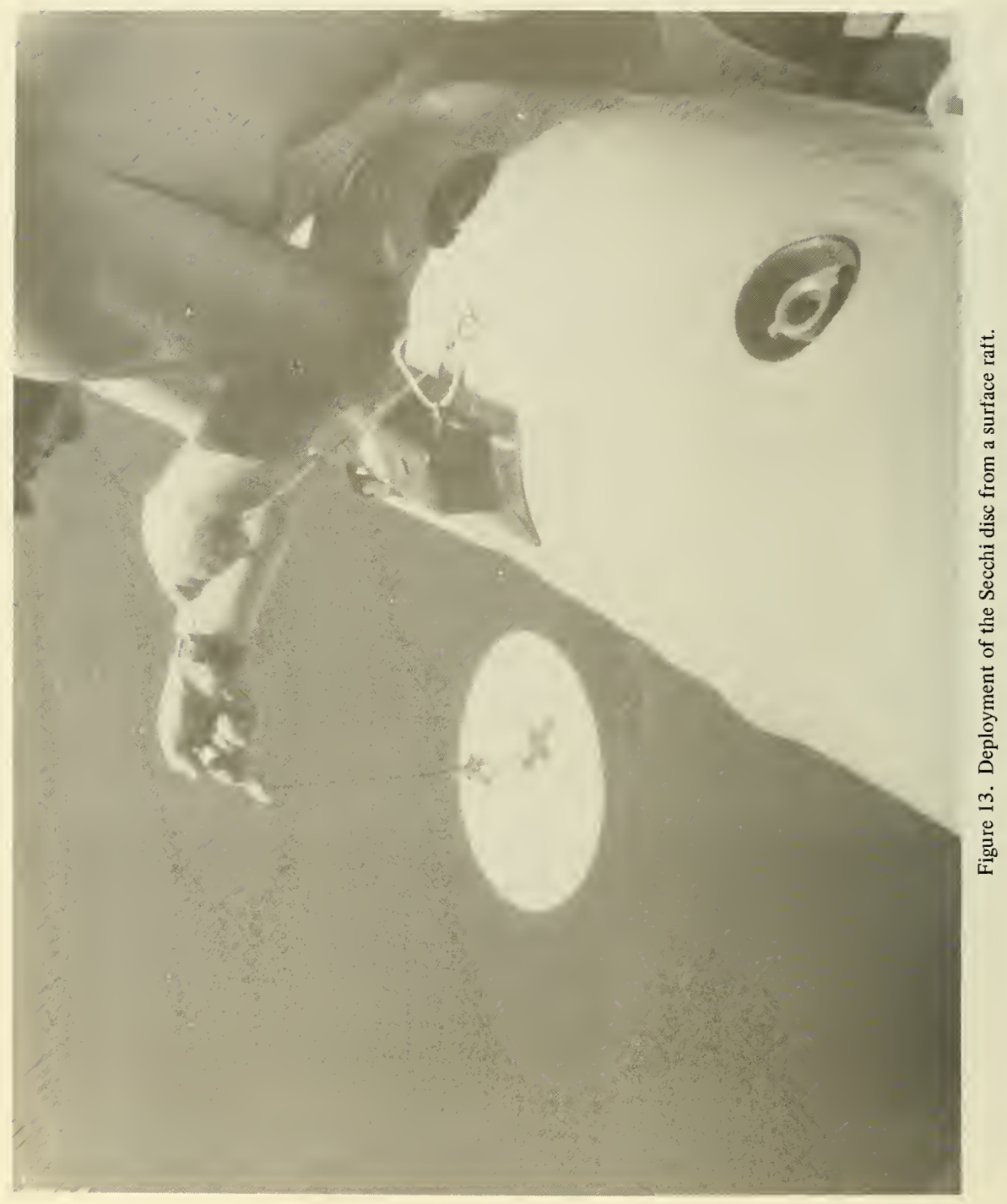




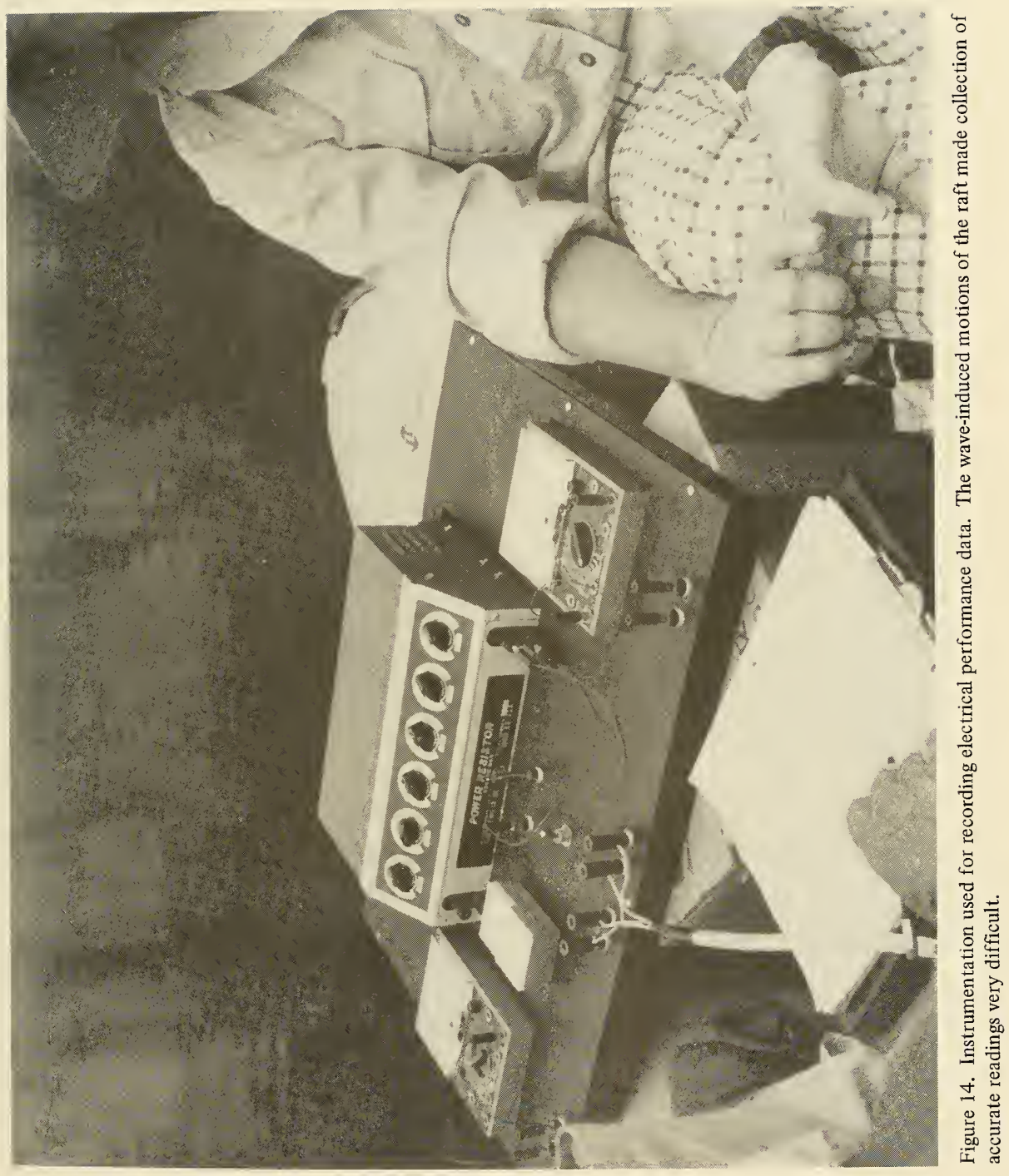


Reduction of Data. Prior to plotting of VI data and calculation of power output, the current readings were standardized at a $80-\mathrm{mW} / \mathrm{cm}^{2}$ insolation level. In this manner, variations between plotted VI and W curves reflected only differences in optical quality of water and not small variations in insolation of the water surface. Two types of graphs were generated: potential as a function of current (VI) and power output as a function of potential (WV) measured at the end of 200 -ft-long pigtails. On the basis of these families of plots, a designer can estimate the size of a submerged solar cell array* needed to power electronic instrumentation with known power and potential requirements.

Test Findings. The electrical performance of upward-facing, horizontally positioned solar cells decreases rapidly with depth after the first 0.25 in $(6 \mathrm{~mm})$ of submersion. Under ideal underwater visibility conditions, represented by water with visibility in the 95 -ft range $(29 \mathrm{~m})$, approximately 40 percent of potential power output is lost in the first $1 \mathrm{ft}(0.3 \mathrm{~m})$ of submersion (figures 15 and 16). With greater submersion the rate of performance deterioration decreases, but even under ideal water clarity conditions the loss amounts to approximately 95 percent at $95 \mathrm{ft}(29 \mathrm{~m})$ and 98 percent at $200 \mathrm{ft}(61 \mathrm{~m})$. In water with visibilities of 16.5 , 8 , and $2.5 \mathrm{ft}, 95$ percent of potential power output loss occurs at approximately 16.5-, 8- and 2.5-ft depths $(5,2.4$, and $0.75 \mathrm{~m}$ ), respectively (figures 17 through 22 ).

The electrical power output of submerged, downward-facing, horizontally positioned solar cells equals approximately 1- to 3-percent power output of upward-facing cells at the same depth (figure 23). The power output of submerged vertically positioned cells depends markedly on their orientation with respect to the sun. Cells facing the sun generate power which approaches the 30-percent level of upward-facing cells with horizontal position at noon and the 70-percent level during early and late hours of the day (figures 24 and 25). Cells facing away from the sun produce power which approaches 5 percent of upward-facing cells with horizontal position. The output of vertically positioned cells that do not face the sun directly falls between the two above mentioned limits.

\footnotetext{
* The performance characteristics of the selected solar cells must match those used in Solarex high-density test panels 100177 and 100178 .
} 


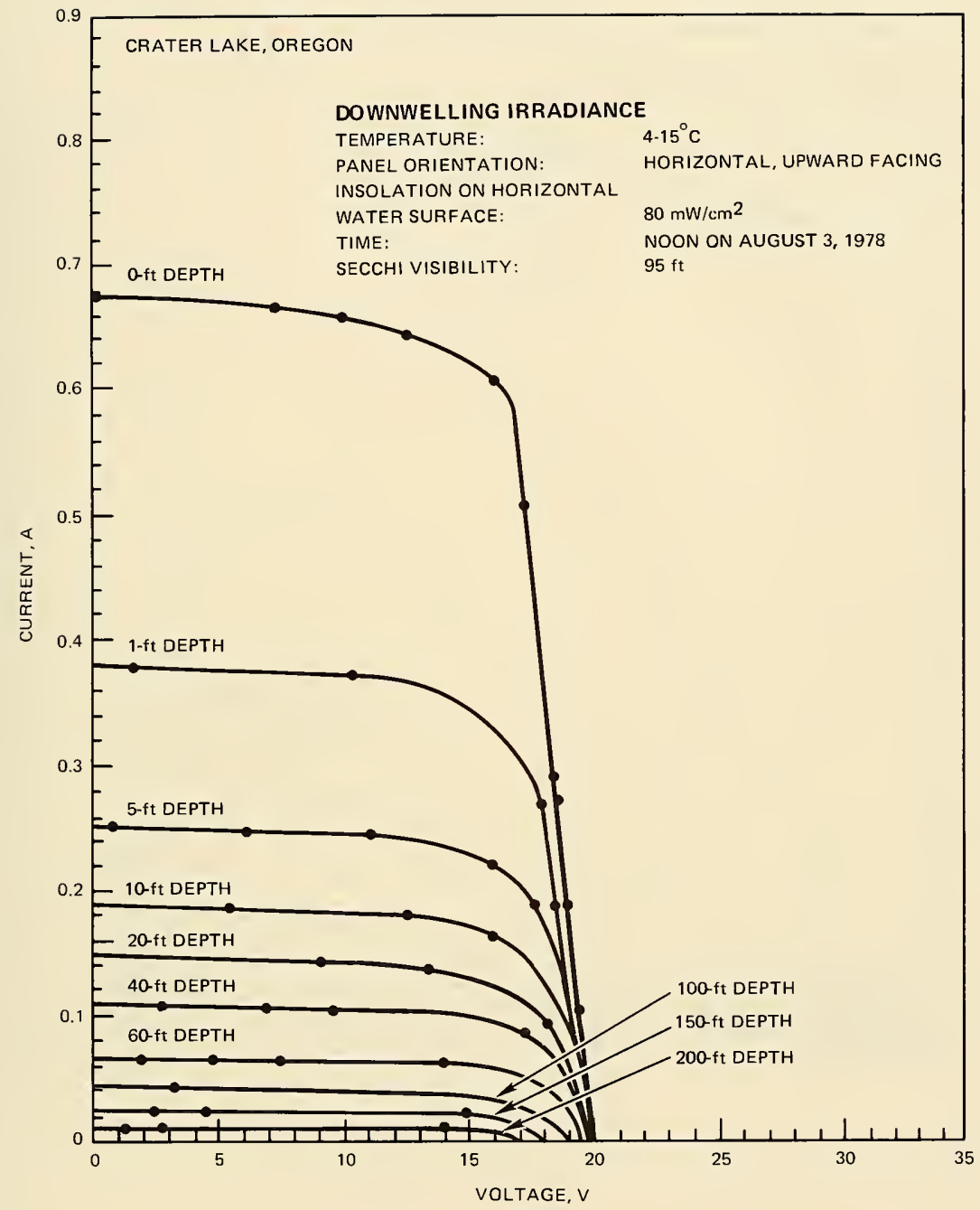

Figure 15. Voltage and current generated by the horizontal, upward-facing solar cell panel at different depths in Crater Lake, Oregon. The average Secchi disc visibility was $95 \mathrm{ft}$. 


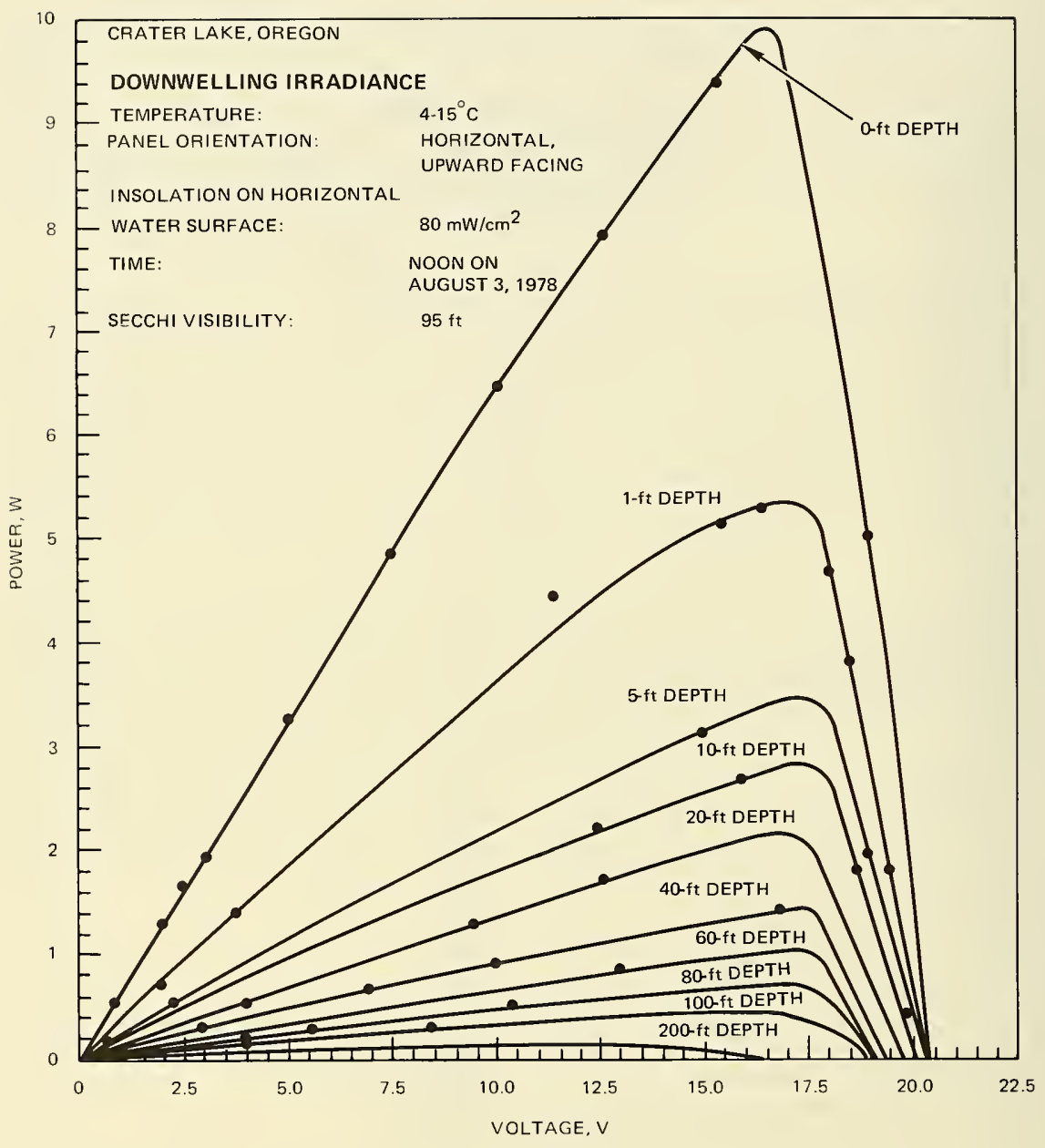

Figure 16. Data from figure 15 replotted to show maximum power output at different depths in Crater Lake, Oregon. 


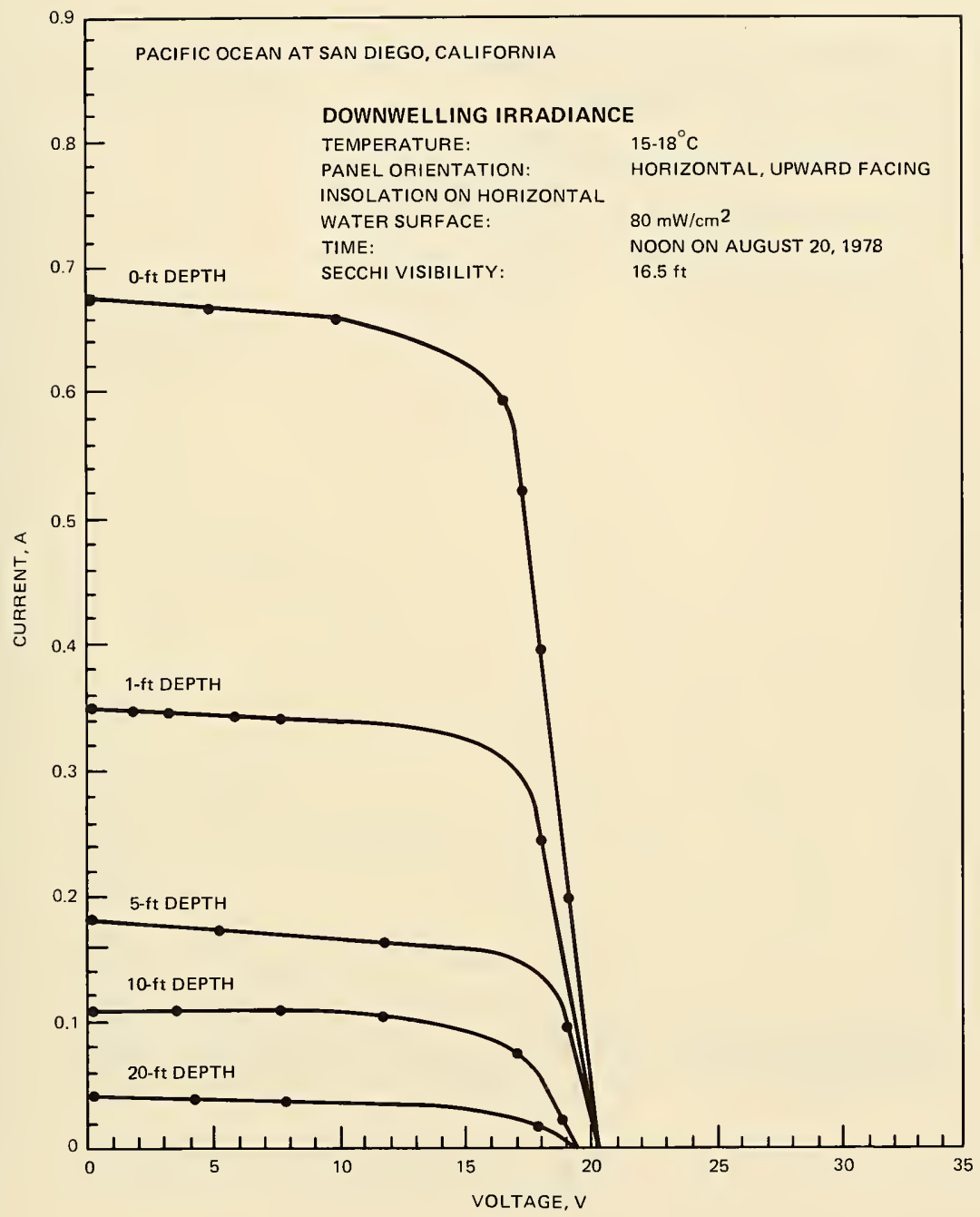

Figure 17. Voltage and current generated by the horizontal, upward-facing, solar cell panel at different depths in Pacific Ocean off Point Loma, California. The average Secchi disc visibility was $16.5 \mathrm{ft}$. 


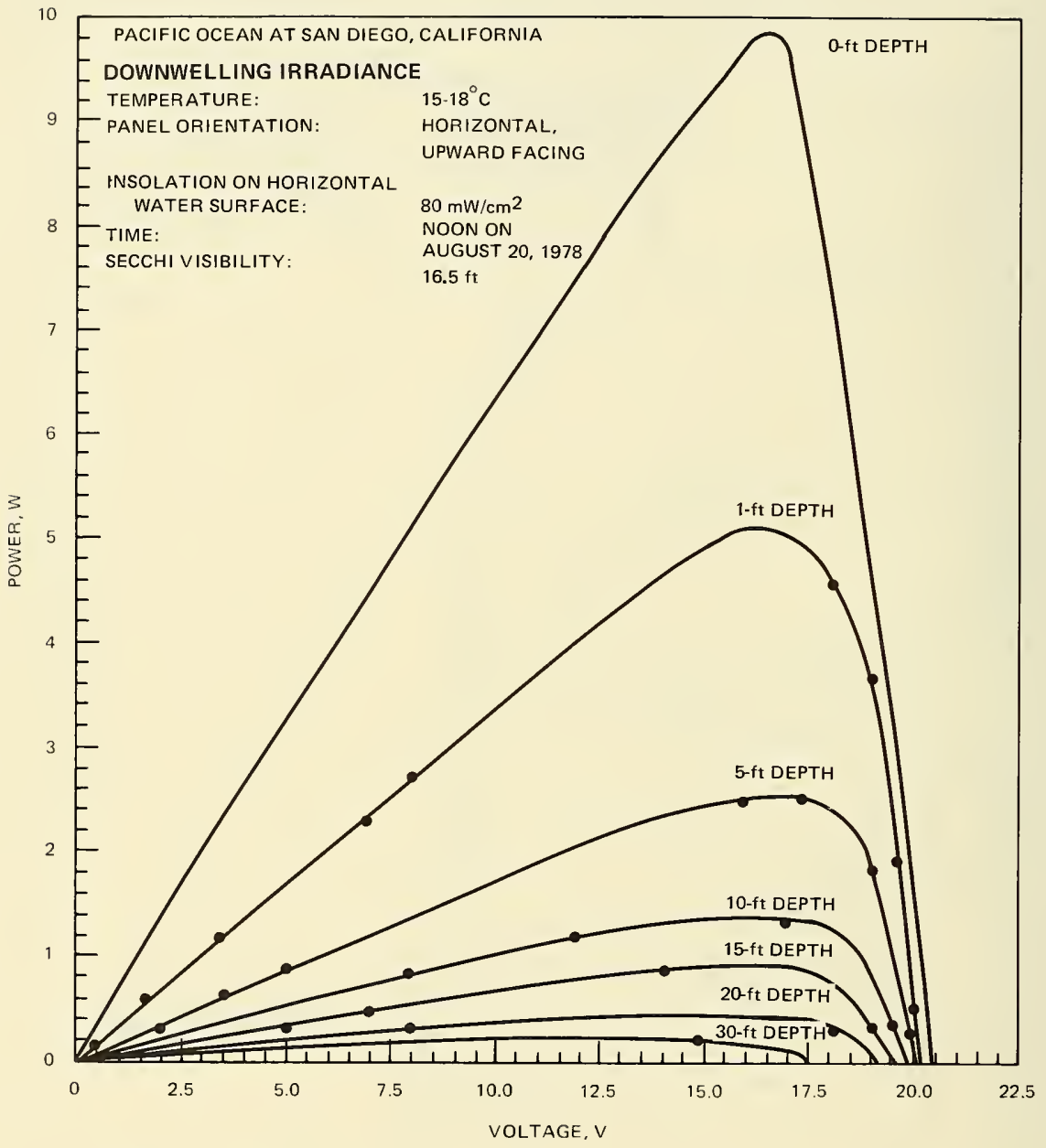

Figure 18. Data from figure 17 replotted to show maximum power output at different depths in Pacific Ocean off Point Loma, California. 


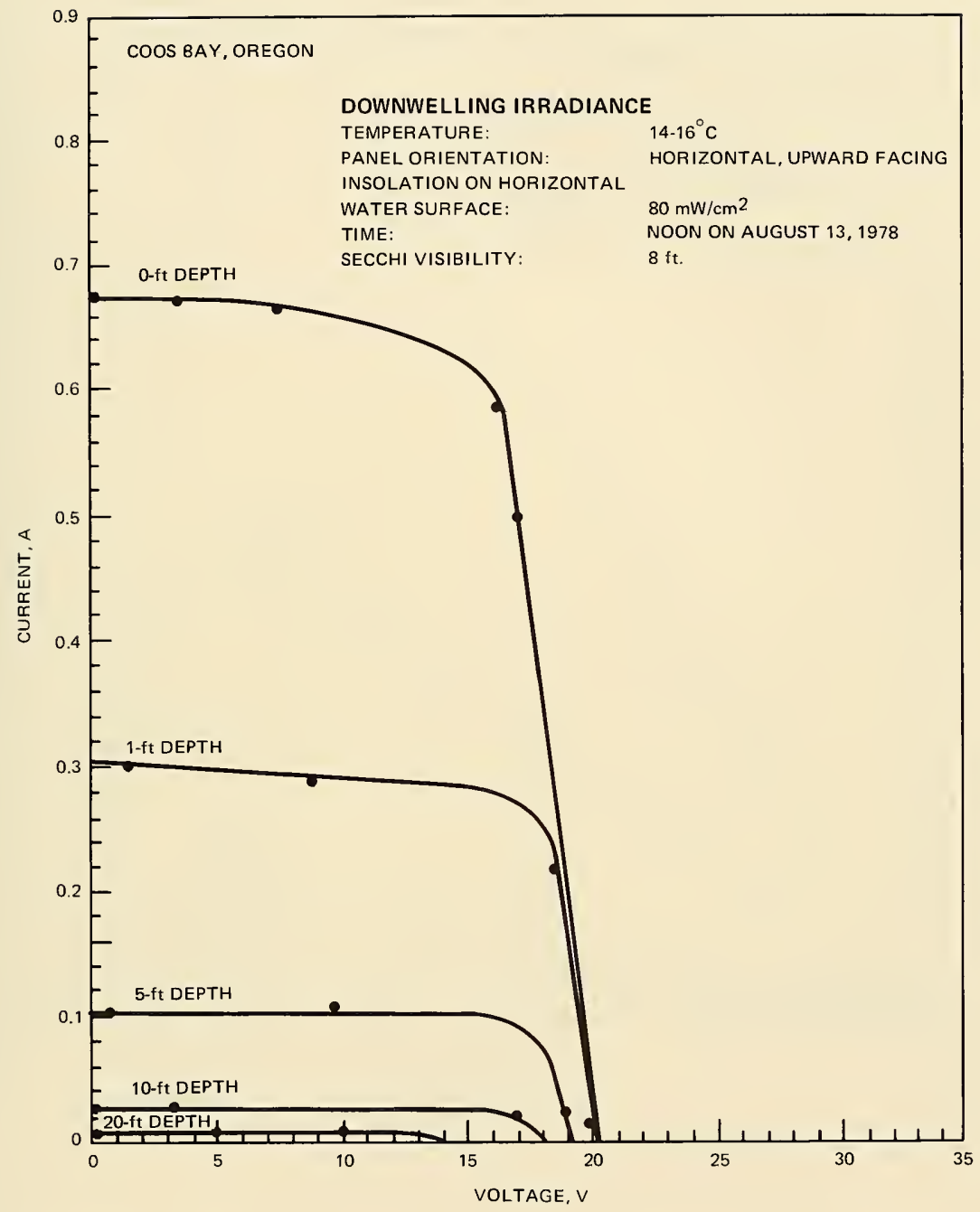

Figure 19. Voltage and current generated by the horizontal, upward-facing, solar cell panel at different depths in Coos Bay, Oregon. The average Secchi disc visibility was $8 \mathrm{ft}$. 


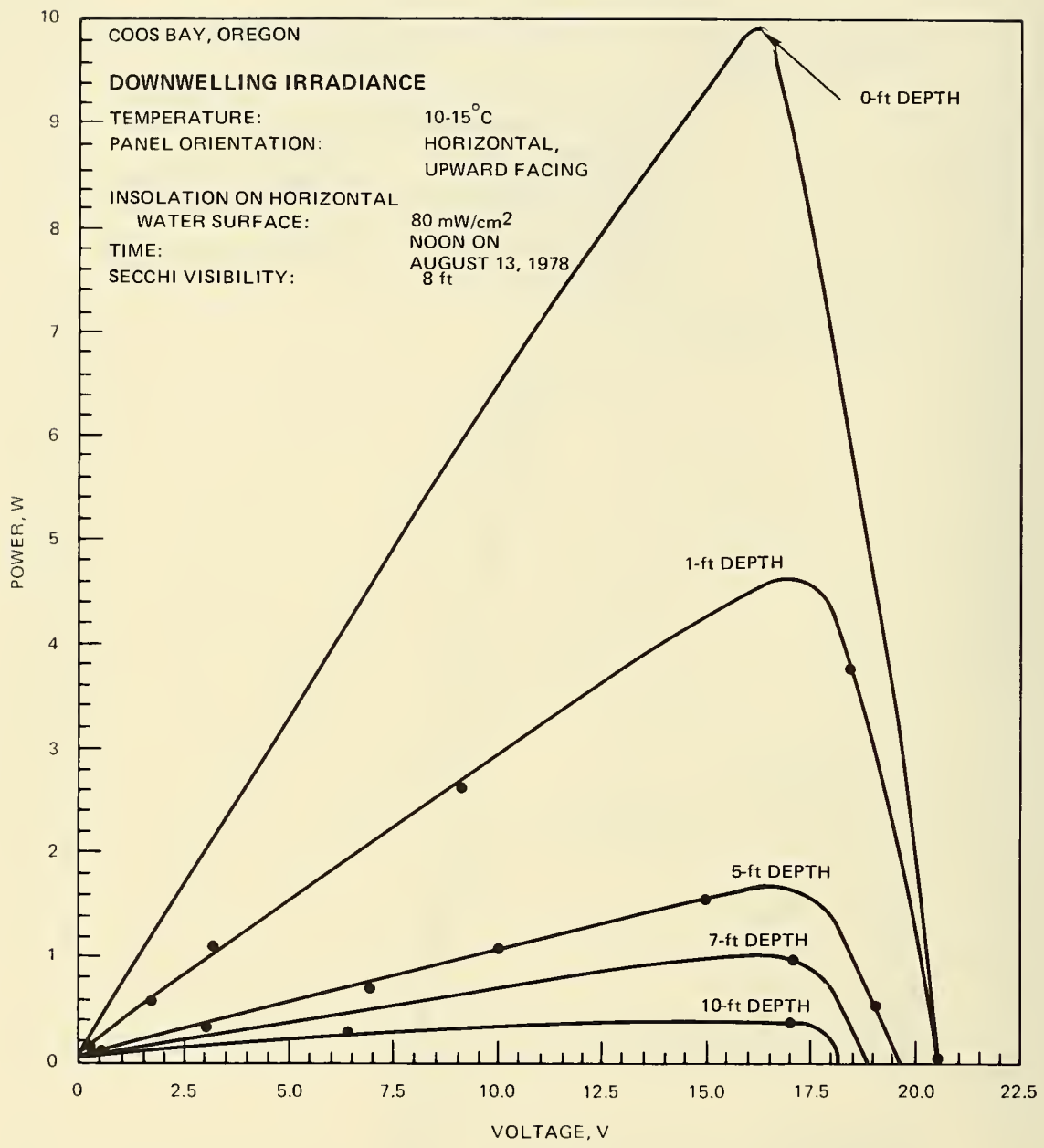

Figure 20. Data from figure 19 replotted to show maximum power output at different depths in Coos Bay, Oregon. 


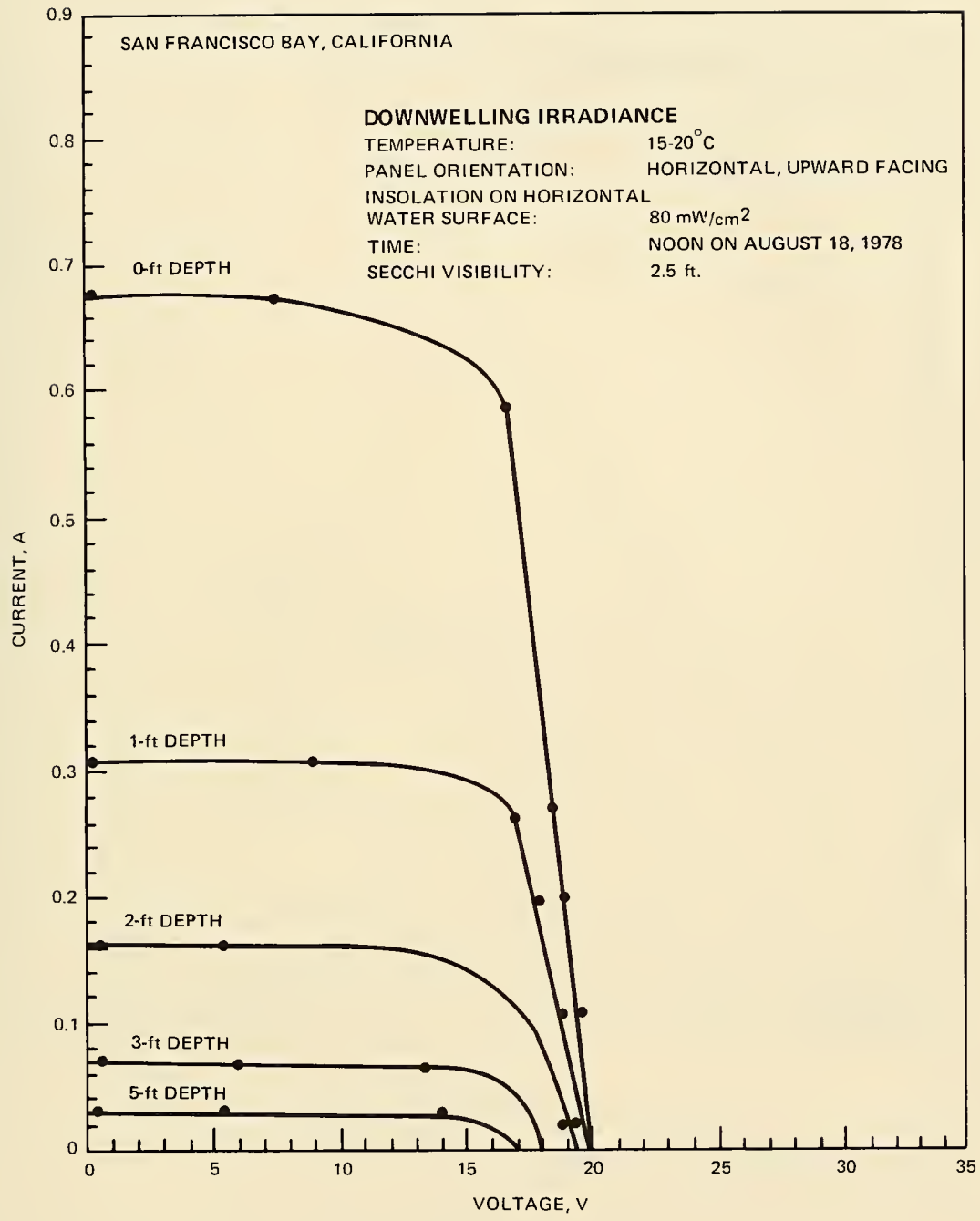

Figure 21. Voltage and current generated by horizontal, upward-facing, solar cell panel at different depths in San Francisco Bay near Martinez, California. The average Secchi disc visibility was $2.5 \mathrm{ft}$. 


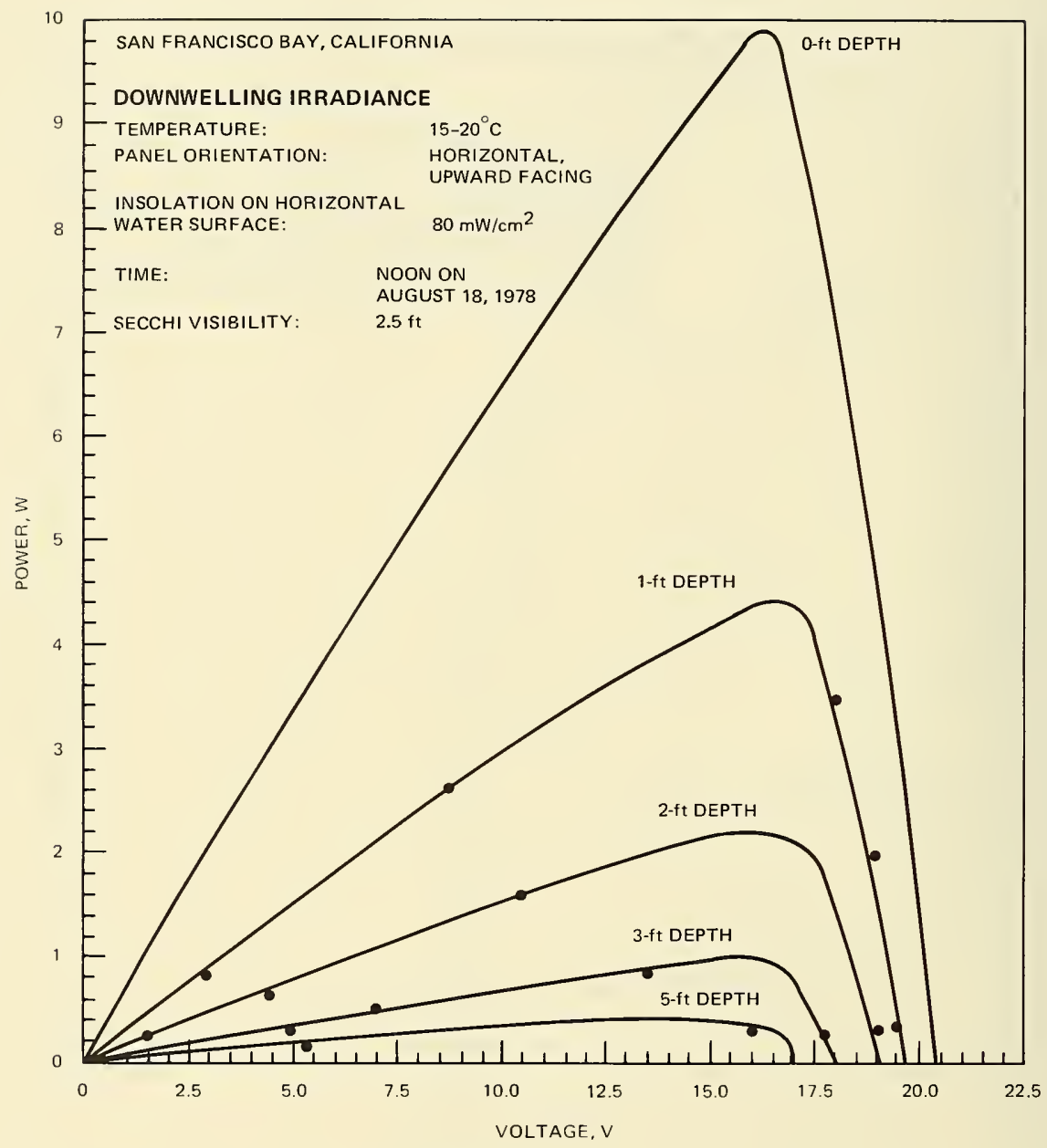

Figure 22. Data from figure 21 replotted to show maximum power output at different depths in San Francisco Bay near Martinez, California. 


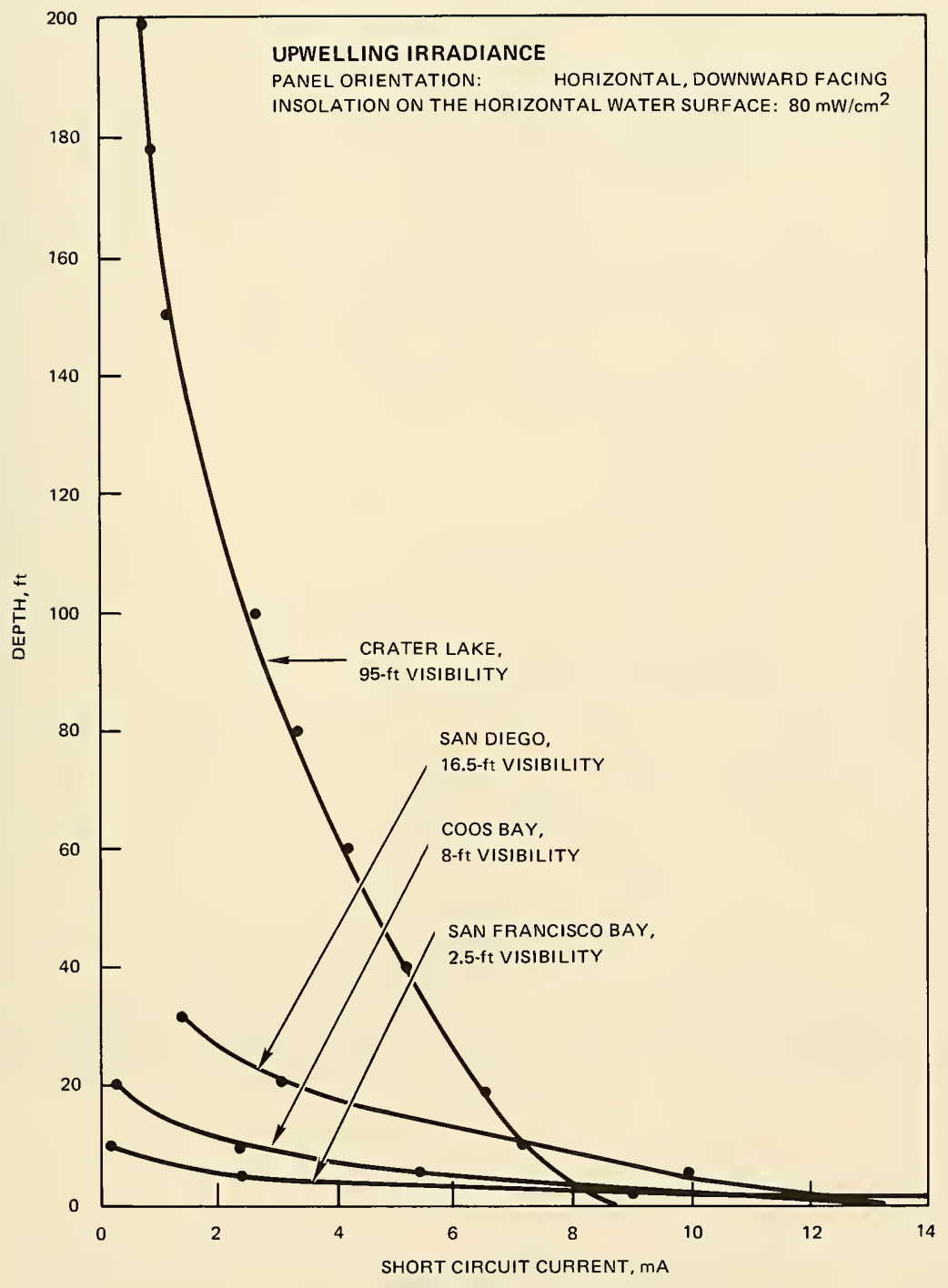

Figure 23. Maximum (short circuit) current generated by the submerged, horizontal, downwardfacing, solar cell panel in locations with different Secchi visibilities. 


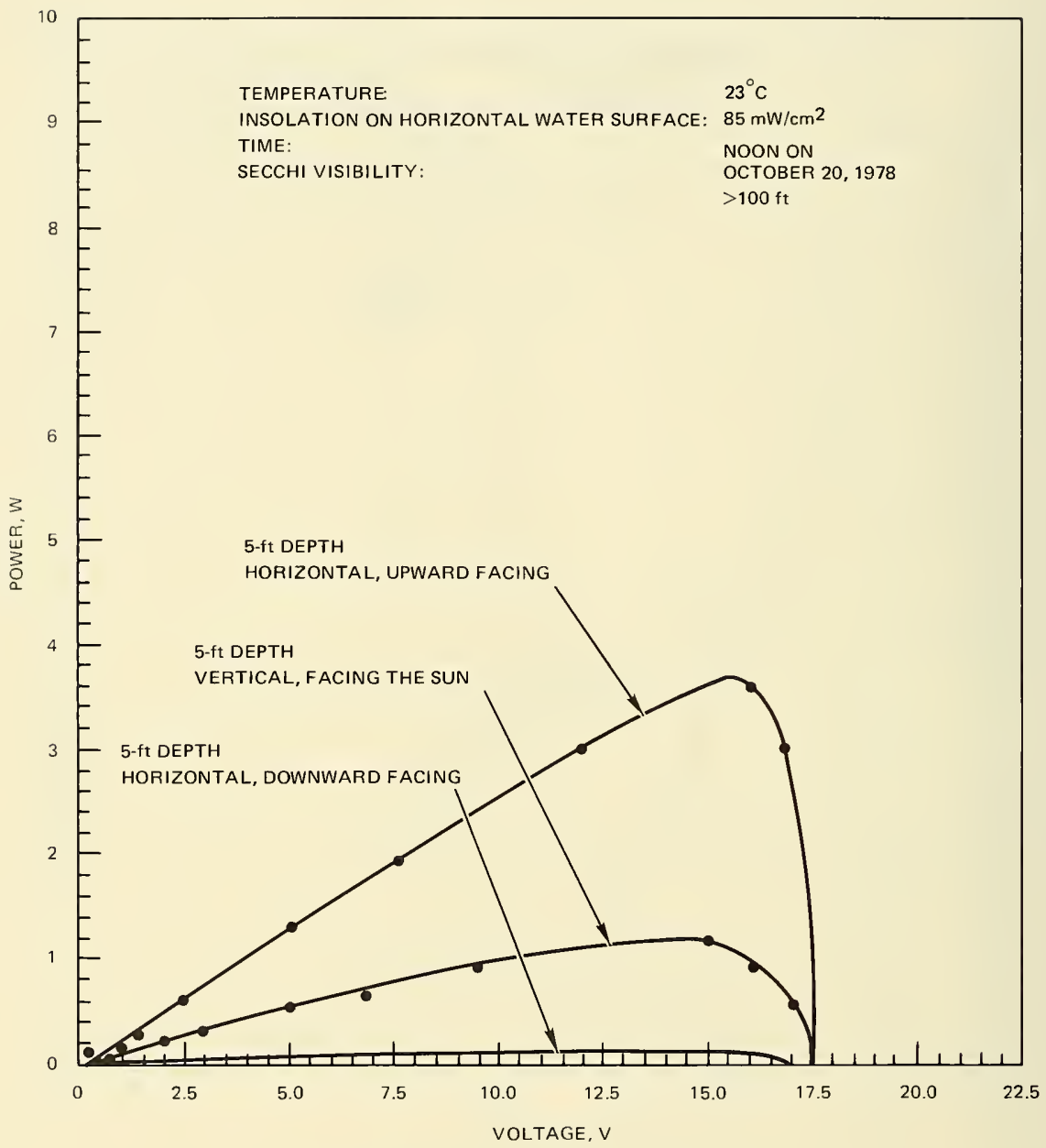

Figure 24. Effect of orientation on the electrical power output of submerged solar panel at 5-ft depth in water with a $100-\mathrm{ft}$ Secchi visibility. 


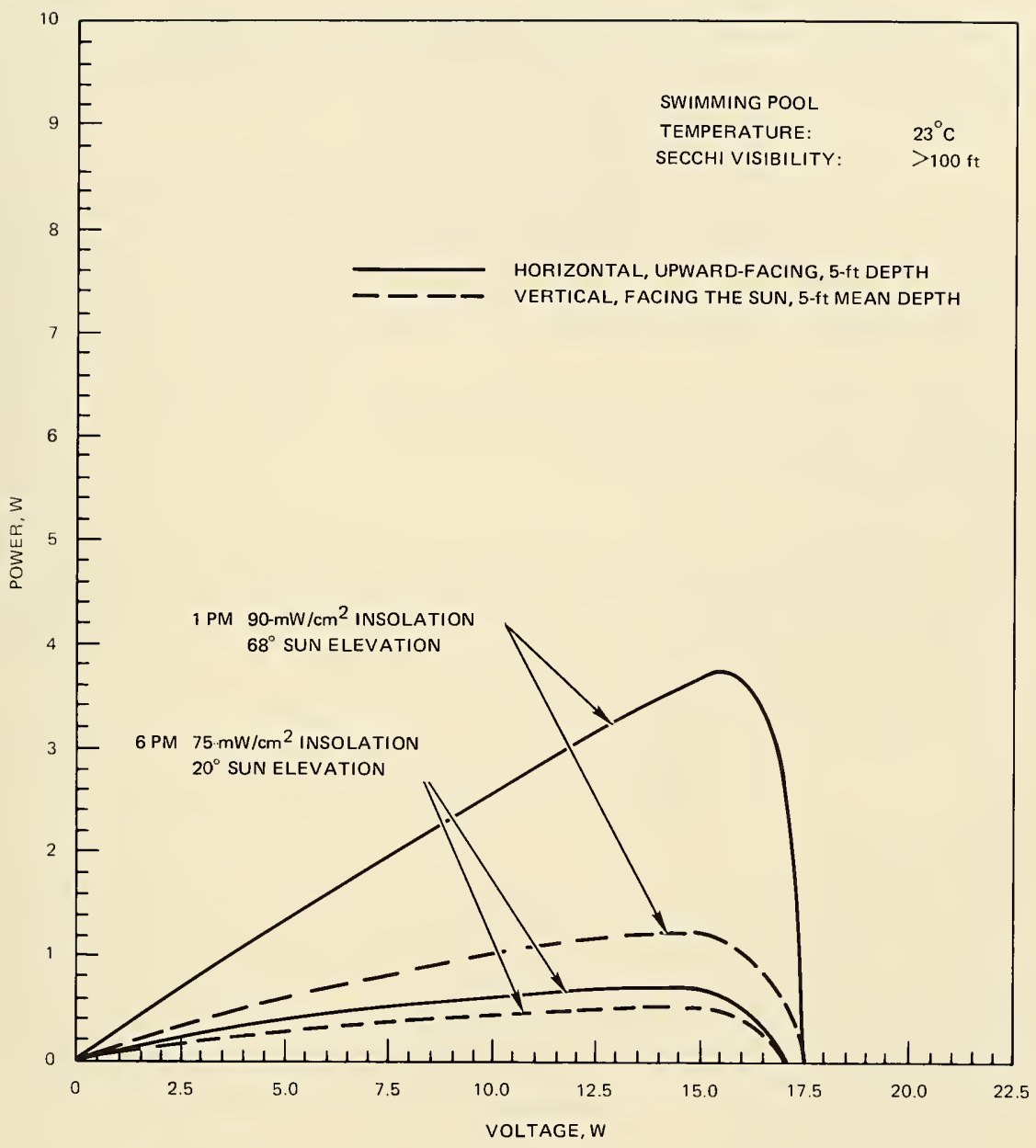

Figure 25. Effect of sun elevation on the electrical power output of submerged solar panel at different orientations. 
Discussion of Test Data. The decrease of power output from solar cells subjected to splash is negligible, but with depth the power output decreases to the point that it becomes practically useless. Insufficient data have been generated to formulate an empirical relationship between the optical properties of water and the power output of horizontally oriented, upward-facing photocells submerged to different depths.

It appears, however, that there is a discernible pattern in the experimental data which allows formulation of an approximate empirical rule for estimating the power output of a horizontally positioned, upward-facing, solar cell submerged to the visual contrast limit depth. The power output of such cells at that depth amounts to roughly 5 percent of the power output which the same cells would provide on the water's surface. With this empirical guide it is feasible to estimate the power output of solar cells in waters with excellent or poor visibility, provided the visual contrast limit depth (underwater visibility) has been experimentally established with a Secchi disc for the body of water in that particular location. This, of course, can be easily accomplished by lowering a 12-in Secchi disc from any vessel and noting the length of line payed-out at the moment that the white Secchi disc becomes indistinguishable from the background.

This empirical rule does not at first appear to be of great help to the designer, until it is realized that this is the maximum desirable depth for submergence of a device to insure escape from visual detection and thus vandalism from surface vessels. The designer may, of course, want to place the buoy at some depth which is below or above the visual contrast limit depth; however, the rule will still state whether the power output will be less or more than 5 percent of the rated potential power output at the water surface.

\section{UTILIZATION OF SUBMERGED SOLAR CELLS}

\section{POWER OUTPUT}

As field tests have shown, immersion of solar cells in water decreases their power output significantly; at depths equal to the visual contrast limit, the available power output is conservatively estimated to be only approximately 5 percent of the potential power output at the surface. If a high-density horizontal solar array is used, * the 5-percent power output translates to approximately $0.6-\mathrm{W} / \mathrm{ft}^{2}\left(6.45 \mathrm{~W} / \mathrm{m}^{2}\right)$ power density at the visual contrast limit depth when the ocean surface is under normal $100-\mathrm{mW} / \mathrm{cm}^{2}$ insolation. Although this is a very low power density, it is still high enough to merit interest from the designer of submerged marine electronic devices.

However, before this power density value can be used for sizing underwater solar cell arrays, the fact that the horizontal ocean surface receives a normal $100-\mathrm{mW} / \mathrm{cm}^{2}$ insolation (standard 1.0 sun radiation) only around noon in the equatorial zone from an overhead sun in a cloudless sky must be considered. At higher latitudes during cloudy weather at late and early hours of the day, the intensity, as well as the inclination of solar insolation striking the ocean surface, will be significantly less than that under standard conditions. To compensate for the variables of insolation intensity and inclination in the calculation of total energy

* Similar to the ones utilized in this study, i.e., Solarex arrays 1017 and 1018 rated at $12 \mathrm{~W} / \mathrm{ft}^{2}$ under normal $100-\mathrm{mW} / \mathrm{cm}^{2}$ insolation. 
supplied by a horizontally submerged array, it is postulated that in latitudes of 30 to $40 \mathrm{deg}$ the total energy input is represented by normal insolation of $80-\mathrm{mW} / \mathrm{cm}^{2}$ intensity falling upon an agitated water surface for an average of $4 \mathrm{hr}$ each day. In the tropics (between the Tropics of Cancer and Capricorn) the same intensity of insolation can be considered to act normally to the water surface for an average of about $5 \mathrm{hr}$ per day. At latitudes above 40 deg the average daily length is about $3 \mathrm{hr}$ and in the polar region less than $1 \mathrm{hr}$.

In practical terms this means that for a horizontal, upward-facing, high-density silicon solar cell array positioned at the visual contrast limit depth, the average daily energy output varies from approximately 0.5 to $2.5 \mathrm{~W}-\mathrm{hr} / \mathrm{ft}^{2}\left(0.5 \mathrm{~W} / \mathrm{ft}^{2} \times\right.$ hours of insolation at $80-\mathrm{mW} / \mathrm{cm}^{2}$ intensity at right angle to the water surface). Thus the square area of solar arrays for a given energy requirement will vary approximately by a factor of 5 between devices designed for tropical and polar regions.

Downward-facing, horizontal solar cell arrays have a power density of less than 0.02 $\mathrm{W} / \mathrm{ft}^{2}$ at the visual contrast limit depth when the ocean surface is normally insolated with solar radiation at $100-\mathrm{mW} / \mathrm{cm}^{2}$ intensity level. For this reason they have very little practical value as a potential power supply for submerged electronic devices unless the devices are submerged to less than the visual contrast limit depth at locations where a white sandy bottom is clearly visible from above the ocean surface. In such cases the reflected light from the ocean bottom can increase the power output of a downward-facing solar cell by as much as an order of magnitude and thus make the power density high enough to be of practical value to the designer.

Vertically positioned solar cell arrays submerged under water deliver more power than the downward-facing horizontal arrays located at an identical depth. The output of the vertically positioned array oriented to face the sun is approximately an order of magnitude larger than that of a vertically positioned array facing away from the sun. The vertically positioned array, facing the sun, produces at noon power equal to about 30 percent of the upward-facing horizontally positioned array, while the array facing away from the sun produces power only equal to about 5 percent of the upward-facing array. Vertically positioned arrays with intermediate orientations between facing the sun and facing away from the sun produce power which falls between the two above mentioned power output limits.

Since vertically positioned solar cell arrays, regardless of their orientation with respect to the sun, have a higher power output density than downward-facing horizontally positioned arrays, they should be preferred over the latter ones by the designer. One further reason for their desirability is that their power output decreases only moderately in the early morning and late afternoon because of slanting sun rays, while the power output of upward-facing horizontally positioned arrays decreases significantly. Thus vertically positioned solar cell arrays are considered to complement the power output of upward-facing, horizontally positioned arrays. An additional reason for using the vertical orientation is that this orientation is easy to achieve by bonding narrow solar panels on the exterior surface of cylindrical buoys along their axis of revolution.

It thus appears that if both the top and exterior surfaces of a cylindrical- or polygonshaped buoy are completely covered with solar cells, an adequate electric energy supply exists to power even the most sophisticated oceanographic or navigational equipment on a year-round basis. Using conservative power density factors, the energy output on a year-round 
basis of a cylindrical buoy with $6 \mathrm{ft}$ diameter and $6 \mathrm{ft}$ length at the visual contrast limit depth is estimated to vary from $80 \mathrm{~W}$-hr/day in the tropics to $16 \mathrm{~W}$-hr/day in the polar regions. The energy output can be doubled by mooring the buoy at only one-half of the visual contrast limit depth or it can be increased by an order of magnitude by allowing the buoy to float awash at the surface of the water.

In this case, selection of depth depends on how secure the deployed buoy is to be from visual detection by surface craft, vandalism, or accidental damage by casual ship transit. Since the average visual contrast limit depth in the open ocean is approximately $33 \mathrm{ft}(10 \mathrm{~m})$, a buoy moored at that depth will be secure from all three dangers. A buoy moored at one-half the visual contrast limit depth, $16.5 \mathrm{ft}(5 \mathrm{~m})$, will still be difficult to detect visually and hard to vandalize, but it will be unprotected from damage by passing ships. Surface-moored or floating buoys will lose all safety and visual protection provided by submersion, but will gain immense increases in power output while still retaining some security from detection by radar.

\section{PROTECTION AGAINST MARINE ENVIRONMENT}

If solar cells are not protected from seawater, the generated electricity will be used to generate hydrogen and oxygen with associated severe corrosion of all solar cell components rather than to power the electronic device inside the buoy. The protection of solar cells from seawater is accomplished by enclosing them in a transparent silicon-rubber potting compound. Optical transmissivity and resistance to surface deterioration may also be enhanced by bonding the light-sensitive surfaces of solar cells to glass or acrylic plastic panels with a transparent adhesive and then potting the backs of the cells and the network of conductors with siliconrubber potting. Although all potting compounds are in some degree permeable to water vapor, thick silicon rubber should provide adequate protection against seawater intrusion for several years.

In either case, unless steps are taken to prevent it, biofouling of the panel surface will occur, dramatically decreasing the intensity of the light which reaches the light-sensitive surface of the solar cells. Without any preventive measures, biofouling is estimated to decrease the intensity of illumination on solar cells submerged in less than $30 \mathrm{ft}$ of water by an order of magnitude within 30 days. There are, however, passive and active techniques for preventing or, at worst, ameliorating the effect of biofouling.

The passive approach consists of applying a transparent, poisonous, chemical coating which slowly leaches a poisonous ingredient into the adjacent film of water. Because the leaching of poisonous ingredients makes the coating ineffective after a period of time, the buoy must be removed periodically from the water and a new coating applied. Transparent coatings with TBTO (tri-butyl-tin oxide) applied to plastic surfaces have kept them free of fouling for up to 60 days of submersion in depths of less than $30 \mathrm{ft}^{4}$ For applications, however, where it is desirable to keep surfaces free of fouling for many months or years without periodic recoating, the passive approach cannot provide the desired protection and an active approach must be used.

4. Stachiw, J.L., and Stachiw, J.D., "Effect of Weathering and Submersion in Seawater on the Mechanical Properties of Acrylic Plastic,” ASME Paper 77-WA/OcE-5, Winter Annual Meeting, 1977, New York. 
To date, two active approaches have been experimented with for minimizing the extent and severity of biofouling. Both approaches rely on periodic mechanical wiping of the surfaces to keep them free of biofouling. The first approach utilizes an electrically driven wiper that cleans the surface for about 1 min several times a day. The wiper may take the form of an elastomeric squeegee or of a revolving brush. In either case, the motor-driven wiper sweeps the surface clean several times a day, thus preventing sealife from establishing a firm foothold on the transparent panel cover. A wiper in the form of a revolving brush was successfully used to keep an acrylic viewport in an underwater habitat free of biofouling for 6 months. 5 Based on this experience there is no doubt that the viewport could have been kept clean for an indefinite period of time, providing the wiper did not malfunction. The second active approach is suitable only for buoys located at those depths where the water is subjected to circular motion imparted by the action of surface waves. The wiping action is accomplished in a random pattern by many wipers that consist of short lengths of plastic rope attached to the buoy around its circumference. The wave-induced circular motion of the water causes the rope's segments to undulate and repeatedly strike the surface of the buoy. The repeated contact between the plastic rope and the panel keeps them free of biofouling.

The advantages of the electrically powered wiper approach are that the wiping action is independent of depth and wave action and that its frequency and duration can be programmed for the severity of biofouling that the panel may encounter during its deployment in the ocean. Its disadvantages are the drain on the energy output of the solar cell panel, the cost of wiper train components, and the increased overall complexity of the buoy. The advantages of the wave-powered wipers approach include its simplicity, independence from electrical power supply, low cost, and high reliability. Its disadvantages are shading of the light-sensitive solar cell surfaces by the presence of many wipers, unpredictability of frequency or duration of wiping action, and dependence on sustained duration of wave actions. Based on these considerations, the electrically powered wipers are preferred unless lack of sufficient power reserve in the installed solar cell array precludes their use.

Thus it can be concluded that, although biofouling at shallow submersion is a serious problem whose effects cannot be ignored, passive and active techniques exist that if incorporated in the submerged solar cell array assembly will insure maximum output of electrical power without the performance degradation caused by biofouling buildup.

\section{DESIGN CONCEPTS}

Solar cell arrays can function as primary or secondary power supplies for all submerged or floating oceanographic and navigational buoys currently powered by batteries and gas or wave-driven electric generators. In many cases the power supplied by the solar cells will be found to be more economical and thus readily acceptable to the user, while in a few cases its cost will be found to be so much higher that there will be no reason to make a change.

The availability of electric power from solar cells also allows the design and deployment of electronic devices in the ocean that have not been considered feasible because

5. Kretschmer, T.R., et al, "Seafloor Construction Experiment SEACON 1,” Technical Report R-817, Civil Engineering Laboratory, Port Hueneme, California, February 1975. 
environmentally safe sources of inexhaustible electric power have not been available. Although the application of solar cells to marine electronic devices is only limited by the imagination of the designer, three specific devices will be discussed in this paper as examples of potential applications for solar cells.

\section{MARKERS FOR UNDERWATER HAZARDS TO NAVIGATION}

Submerged rock pinnacles, sunken ships, and collapsed offshore oil production platforms that are submerged less than $40 \mathrm{ft}$ below the water surface pose a grave danger to shipping. Because of subsurface and surface turbulences associated with these obstacles it is rather difficult to mark such subsurface hazards to navigation with standard surface navigational buoys. It would be rather easy, however, to fasten an acoustic transponder to the submerged obstacle which would warn approaching ships of the hidden danger.

Because of the close proximity to the ocean surface, the batteries in the transponder would always be fully charged by the solar cell array, while at the same time the submerged location of the device would protect it from vandalism and storm damage. Although most ships are not now equipped to interrogate such submerged acoustic transponders, they would rapidly acquire such equipment once it became known that underwater hazards were marked in such a manner.

\section{UNDERWATER SENTINELS}

A difficult problem facing law enforcement at sea is denying access to restricted areas by casual or intentional trespassers. Such restricted areas may be fishlife refuges, sensitive naval installations, oil fields, or oil shipping terminals. Although restricted areas are generally marked around their perimeter by surface buoys equipped with appropriate warning signs and/or equipment, they are easily avoided, ignored, and often vandalized. Hidden electronic sentinels that respond only to vessels that fail to emit the appropriate sonic password are necessary.

To be effective, such sentinels would have to be subsurface buoys whose locations could not be ascertained by the intruder with the help of radar or visual observation. The buoy would be equipped with a sensitive hydrophone capable of distinguishing between typical propeller sound and ambient sea noise. If the sound of a rotating propeller was not accompanied by the appropriate acoustic password radiated from a hydrophone on the intruding ship, the sentinel would classify the intruding vessel as a trespasser, extend a whip antenna through the water surface, and alert by radio the central monitor. Since the power consumption of passive listening devices is rather low, the solar cells mounted on top of the buoy would have no difficulty in keeping the batteries charged for round-the-clock operation.

\section{ROVING PATROL}

Of the major challenges faced by all maritime nations, patrolling the continental shelf is probably the greatest. Patrolling by manned surface vessels and aircraft requires a significant expenditure of funds, not only for construction of ships and aircraft, but also for 
their subsequent manning, maintenance, and operation. Significant savings without loss of effectiveness could be achieved by substituting remotely controlled unmanned craft for manned surface vessels and aircraft. By powering these robots with solar cells their cost of operation would be low and their stationkeeping ability or range virtually unlimited.

The unmanned surface patrol vessel can be conceived as a narrow, long submarine sufficiently ballasted with lead batteries to have its flat deck continuously awash. The solar cells mounted on the flat deck would provide sufficient power to keep the vessel on a preset location or course during day and night regardless of wind, wave, or current conditions. The unmanned patrol submarine would be equipped with passive sonar, active radar, television cameras, IR imaging systems, and associated radio and video transceivers. The passive sonar would be either mounted on the hull of the vessel or towed behind on a long cable. The other systems, however, would be mounted on a hydrodynamically streamlined sensor mast to keep them above the water spray generated by waves breaking on deck.

To conserve power, only few sensors would be activated at all times. Other systems would become only activated when triggered by an appropriate signal from the sonar indicating the presence of a surface target in the near vicinity of the patrol vessel. If needed, the patrol vessel would depart from its assigned location and steer an intercept course for positive identification of a suspicious surface or submerged target. If eminent danger exists that the patrol vessel may be rammed or seized by a hostile target, it would emit a radio distress signal and dive to a predetermined depth for cover. In some cases it may also submerge to obtain a better signal-to-noise ratio of a submerged vessel transiting through its patrol area. Upon surfacing, the gathered information would be transmitted by radio to the central monitor.

The patrol functions of the surface vessel would be augmented and complemented during day by a solar-cell-powered drone aircraft equipped with television transceivers. The drone would cruise above the surface patrol vessel at such an altitude that two neighboring surface patrol vessels would be visible at all times.

The patrolling activity of the surface vessel and aircraft would be coordinated by a satellite or family of solar-powered satellites orbiting overhead and relaying all information gathered by patrolling craft to a central command post. Since solar-cell-powered aircraft drones have already been built and experimentally flown with success, there is no technological barrier to implementing the concept of remotely controlled, solar-cell-powered patrol aircraft.

\section{CONCLUSION}

Solar cells have been found to perform successfully underwater, although their power output is significantly reduced with increasing depth of submersion. As a result of this power output decrease, the ultimate visual contrast limit depth, which varies from 2.5 to $95 \mathrm{ft}$ depending on the type of water and location, is considered to be the practical limit for the depth of the solar cell submersion. At this depth, the power output of solar cells has already decreased by 95 percent from the value measured above water surface.

The power output density of submerged solar cells located in the depth range between the ultimate visual contrast limit depth and the water surface is considered to be adequate for 
operation of most typical oceanographic and navigational devices. In addition, the availability of the new, environmentally safe source of electric power will allow the design and deployment of marine electronic devices for oceanographic, navigation, and defense purposes.

\section{REFERENCES}

1. Kelly, B.P., Eckert, J.A., and Berman, E., "Investigation of Photovoltaic Applications," presented at International Congress on The Sun in the Service of Mankind, July 1973, Paris, France.

2. Schenck, H., Jr., and Kendall, H.W., “Underwater Photography,” Cornell Maritime Press, Cambridge, MD, 1957.

3. Tyler, J.E., and Smith, R.C., "Measurements of Spectral lrradiance Underwater," Gordon and Breach Science Publishers, New York, NY, 1967.

4. Stachiw, J.L., and Stachiw, J.D., "Effect of Weathering and Submersion in Seawater on the Mechanical Properties of Acrylic Plastic," ASME Paper 77-WA/OcE-5, Winter Annual Meeting, 1977, New York.

5. Kretschner, T.R., et al, "Seafloor Construction Experiment SEACON 1," Technical Report R-817, Civil Engineering Laboratory, Port Hueneme, California, February 1975.

6. Larson, D.W., “Temperature, Transparency, and Phytoplankton Productivity in Crater Lake, Oregon," Journal of Limnology and Oceanography, Volume 17, May 1972. 
